\title{
Expanding Access, Participation, and Success in International Baccalaureate Programmes (IB Access Project): Evaluation Report Year Two
}

Gail Gerry

Thomas B. Corcoran

University of Pennsylvania, tomc@gse.upenn.edu

Follow this and additional works at: https://repository.upenn.edu/cpre_researchreports

Part of the Education Policy Commons, International and Comparative Education Commons, Urban Education Commons, and the Urban Studies Commons

\section{Recommended Citation}

Gerry, Gail and Corcoran, Thomas B.. (2011). Expanding Access, Participation, and Success in International Baccalaureate Programmes (IB Access Project): Evaluation Report Year Two. CPRE Research Reports.

Retrieved from https://repository.upenn.edu/cpre_researchreports/64

View on the CPRE website.

This paper is posted at ScholarlyCommons. https://repository.upenn.edu/cpre_researchreports/64

For more information, please contact repository@pobox.upenn.edu. 


\title{
Expanding Access, Participation, and Success in International Baccalaureate Programmes (IB Access Project): Evaluation Report Year Two
}

\author{
Abstract \\ In the fall of 2009, the Bill and Melinda Gates Foundation funded a three-year project proposed by the \\ International Baccalaureate (IB) to demonstrate the feasibility of increasing the participation of minority \\ students and students in poverty in its Middle Years Programme (MYP) and Diploma Programme (DP) in \\ selected school districts in the United States. "Expanding Access, Participation and Success in IB \\ Programmes" or the IB Access Project, as it has come to be known, is utilizing a multi-faceted technical \\ assistance and materials development strategy to strengthen IB programs and broaden access for \\ students previously excluded in the Anne Arundel County Public Schools, the Metropolitan Nashville \\ Public Schools, and the Palm Beach County Public Schools. This is a report on the progress made in the \\ second year of the project. \\ Disciplines \\ Education Policy | International and Comparative Education | Urban Education | Urban Studies

\section{Comments} \\ View on the CPRE website.
}


Expanding Access, Participation, and Success in International Baccalaureate Programmes (IB Access Project)

\author{
Evaluation Report: Year Two
}

\author{
Prepared by \\ Gail Gerry and Tom Corcoran \\ The Consortium for Policy Research in Education \\ Teachers College, Columbia University
}

September, 2011 


\section{Table of Contents}

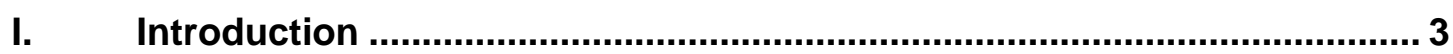

Goals and Objectives of the Project.................................................... 3

The IB Access Project Logic Model....................................................... 3

II. Background on the Pilot Districts and Schools ..................................... 4

Anne Arundel County Public Schools, Maryland........................................ 5

The Metropolitan Nashville Public Schools, Tennessee ………………....... 5

The School District of Palm Beach County, Florida ……............................. 6

The Eight High Schools .................................................................. 7

III. Project Evaluation Activities ............................................................... 8

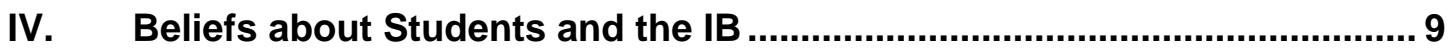

V. Teaching Practices......................................................................... 11

Preparedness and Use of Instructional Practices ………....................... 15

Preparedness and Use of IB Practices and Tools................................... 16

Relationship between Preparedness and Use ...................................... 17

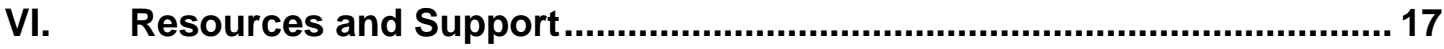

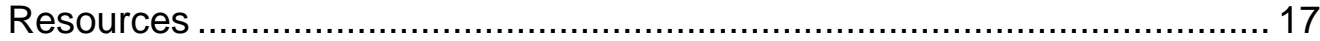

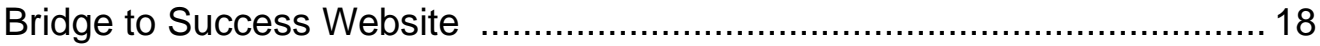

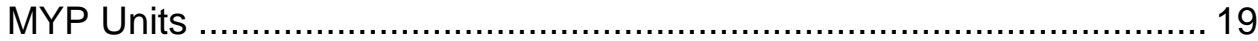

The Assessment Task Bank ........................................................... 21

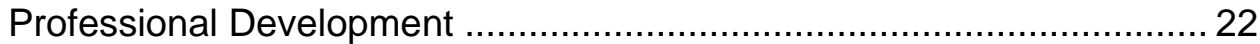

Blended professional development ............................................... 22

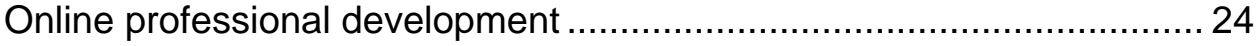

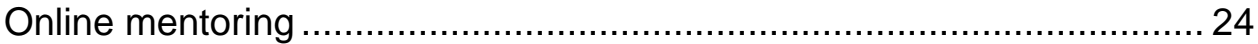

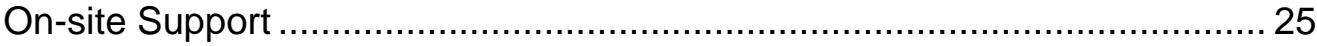

Teacher Response to On-site Support ................................................ 26

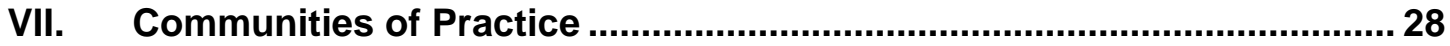

VIII. Student Success and Underrepresented Students............................... 31

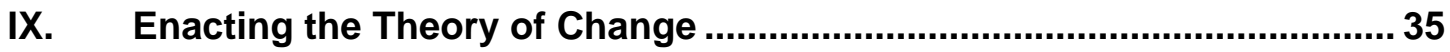

District and School Theory of Change Components ……............................ 37

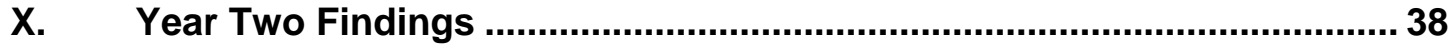

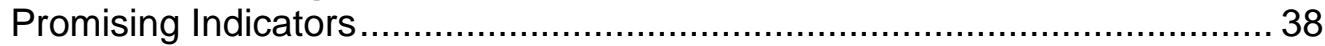

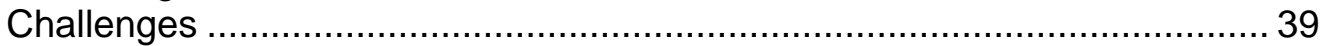

XI. Year Three Research Priorities .............................................................. 40

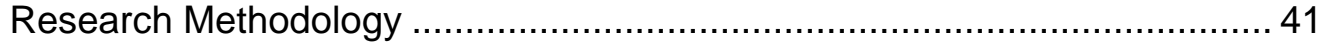

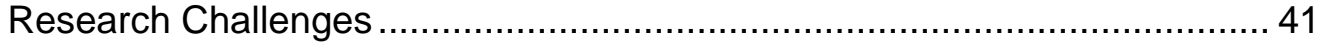

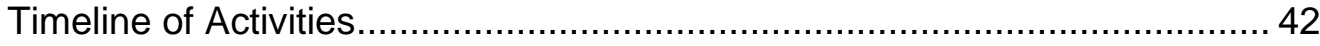

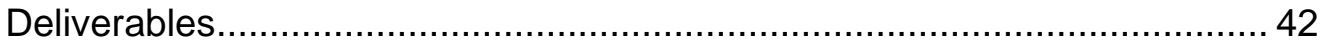

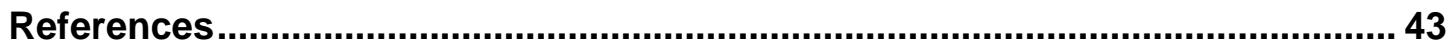




\section{List of Figures and Tables}

Figure 1: The IB Access Logic Model Graphic................................................ 4

Table 1: Characteristics of the Participating High Schools ...................................... 8

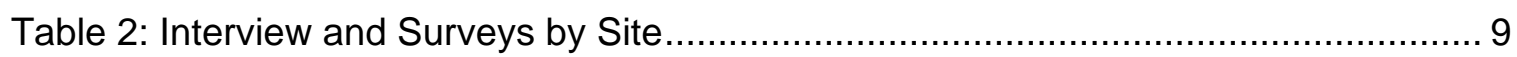

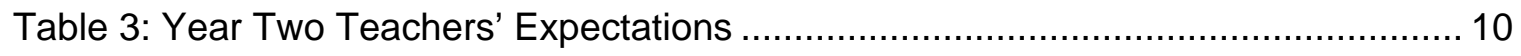

Table 4: Teacher Preparedness to Use Good Teaching Practices ............................ 13

Table 5: Frequency of Use of Good Teaching Practices ..................................... 14

Table 6: Correlations between Preparedness and Use of Instructional

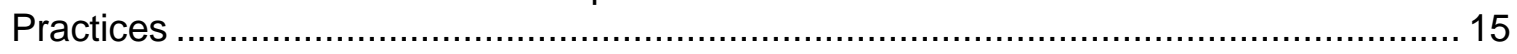

Table 7: Teachers' Preparedness to Use IB Practices and Materials........................ 16

Table 8: Teachers' Reported use of IB Practices and Materials ............................... 16

Table 9: Correlations between Preparedness and Use of IB Practices ....................... 17

Table 10: Use and Utility of the Bridge to Success Website by School ....................... 18

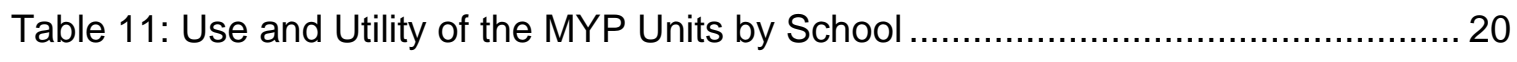

Table 12: Use and Utility of the Assessment Task Bank ........................................ 22

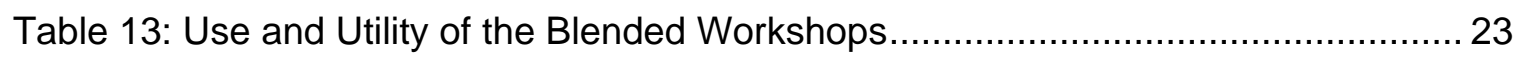

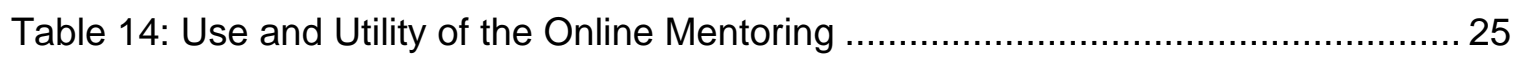

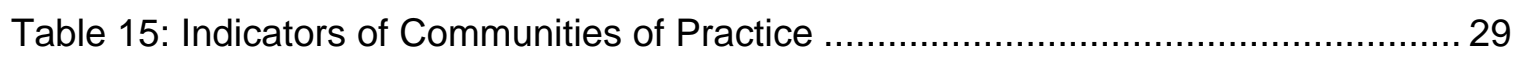

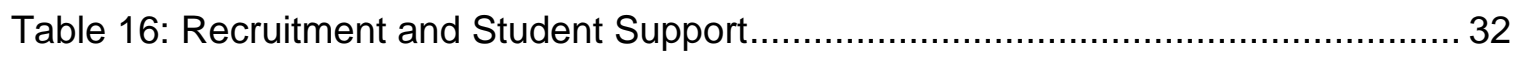




\section{Introduction}

In the fall of 2009, the Bill and Melinda Gates Foundation funded a three-year project proposed by the International Baccalaureate (IB) to demonstrate the feasibility of increasing the participation of minority students and students in poverty in its Middle Years Programme (MYP) and Diploma Programme (DP) in selected school districts in the United States. "Expanding Access, Participation and Success in IB Programmes" or the IB Access Project, as it has come to be known, is utilizing a multi-faceted technical assistance and materials development strategy to strengthen IB programs and broaden access for students previously excluded in the Anne Arundel County Public Schools, the Metropolitan Nashville Public Schools, and the Palm Beach County Public Schools. This is a report on the progress made in the second year of the project.

\section{Goals and Objectives of Project}

The IB Access Project seeks to do four things:

- Improve teacher practice in designing curriculum and assessment that prepares students for the DP by providing new resources designed for this project through professional development and instructional support.

- Improve teacher access to resources for effective assessment design including increased use of online learning environments.

- Increase teacher on-site professional support around classroom practice.

- Increase participation of low-income and minority students in the pilot districts in both certificate courses and in the full DP.

\section{The IB Access Project Logic Model}

The draft theory of action for the IB Access Project is illustrated in Figure I below. It is a relatively straightforward theory, holding that if previously excluded students are actively recruited into the MYP, provided with adequate encouragement and support, and encounter teachers who are well-prepared to assist them because they have been equipped with new tools for instruction and received professional development on teaching strategies, then higher proportions of these students will succeed in the IB Middle Years Programme, and continue into the IB Diploma Programme.

Basically the IB Access Project rests on the following assumptions:

1. Individuals are motivated to act when the potential rewards are compelling; the likelihood of success is high; and the risks of failure acceptable.

2. Changing behavior is a powerful way of changing attitudes so that the provision of new instructional routines and tools for teachers can alter their beliefs about who can benefit from IB, and similarly, active recruiting and provision of new supports can overcome student and parent beliefs about their chances of success in the IB program. 
The evaluation is focused on the changes observed in the composition of the student population, the use of the new instructional tools and participation in the professional development, teacher perceptions of the progress of the students and the efficacy of the new tools, and changes in the outcomes for the newly recruited students. The timeframe of the project will not allow for tracking the new students' success on the IB examinations themselves, but other outcomes such as participation in the DP, as well as teacher perceptions of the students' progress, will be tracked.

\section{Figure 1: The IB Access Logic Model Graphic}

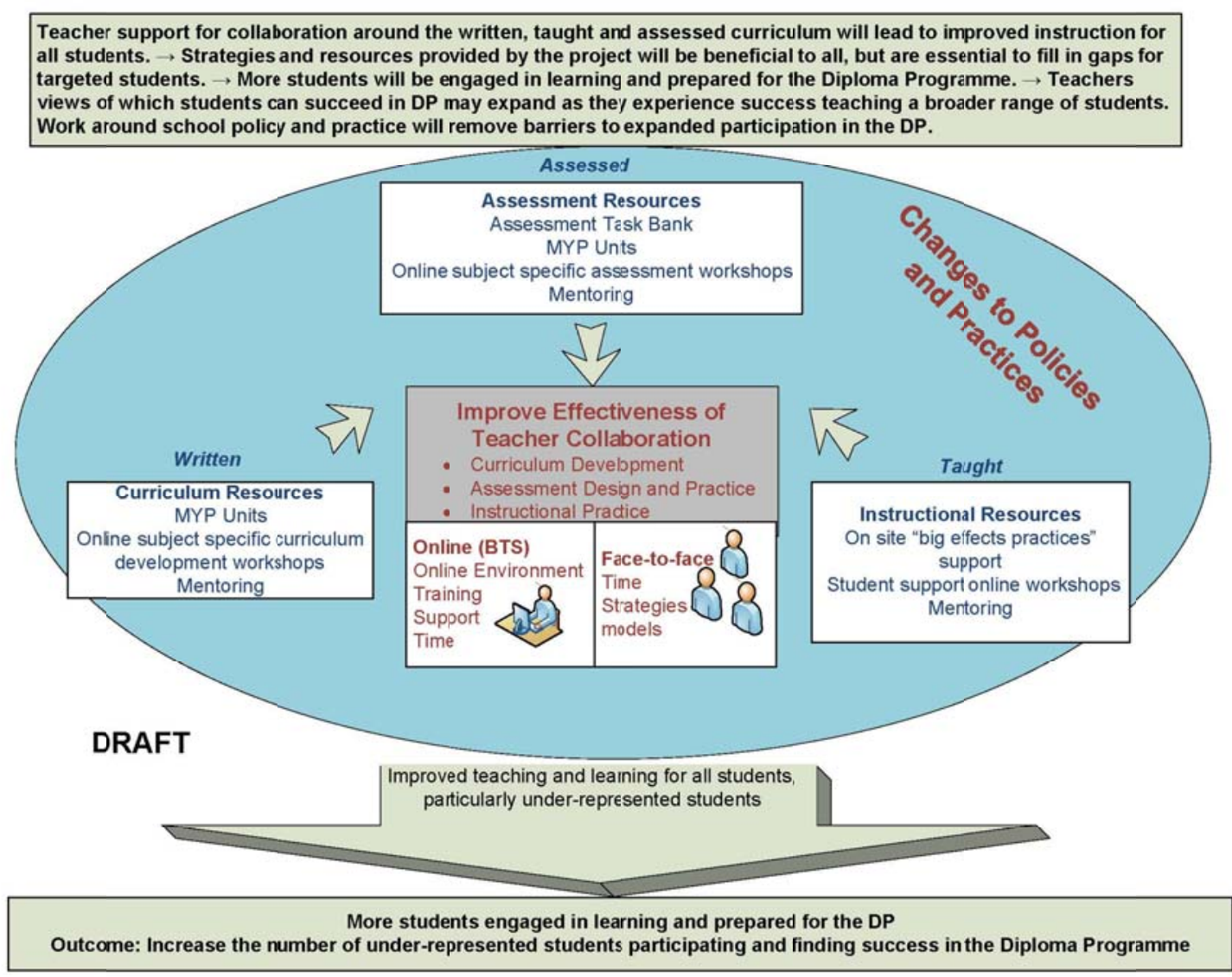

\section{Background on the Pilot Districts and Schools}

Three districts were selected for this project: Anne Arundel County Public Schools, Maryland; Metropolitan Nashville Public Schools, Tennessee; and The School District of Palm Beach County, Florida. A total of eight high schools are included in the project: three in Anne Arundel; two in Metro Nashville; and three in Palm Beach County.

\section{Anne Arundel County Public Schools, Maryland}

Anne Arundel County Public Schools (AACPS) serves approximately 75,500 students and has 5,500 teachers among 125 schools. With district offices located in Annapolis, Maryland, the state capital, there is considerable pressure on the district leaders to show academic gains. The district spans the Chesapeake Bay and the I-95 corridor 
and is about one hour from Baltimore and one hour from Washington, DC. Dr. Kevin Maxwell is entering his sixth year as superintendent and the system operates under a Strategic Plan that focuses on academics and equity. AACPS spends approximately $\$ 12,299$ per student and students score above the state average on SATs and state assessments. The racial composition of the district is as follows: $65.5 \%$ white; $23 \%$ African American; 7\% Hispanic; 4\% Asian; and .5\% American Indian.

The IB program is administered by the Curriculum/Instruction Department in the Advanced Programs area. There is a full-time district coordinator who has oversight for the Primary Years Programme (PYP), the MYP, and the DP. The IB program is currently considered to be a magnet program and application to the program is made centrally for admission to one of the three participating high schools in the region of a student's "home" school. Currently, students apply for the MYP in eighth grade and can be admitted via three different pathways.

Three high schools are fully authorized to offer the DP and also offer magnet students the MYP; all three schools are participating in the IB Access Project. Previously, the MYP was called the Extended Learning Program or ELP which was an interim step to allow the schools to prepare for authorization and full-scale MYP implementation. These three comprehensive high schools-Annapolis High School, Meade Senior High School, and Old Mill High School—are all fed by middle schools that also offer the MYP. The MYP in the three high schools and the feeder middle schools were all officially authorized in August 2010 following school visits in the spring.

Changes from Year 1 to Year 2 include the following: a new MYP and new DP coordinator at Old Mill HS and a new assistant principal assigned to support IB; no extended pay for staff at Annapolis HS as part of their three-year restructuring; and a district focus on creating several PYPs in elementary schools. For Year 3 there will be a new principal at Old Mill HS and all ninth and tenth grade students in the three pilot schools will participate in the MYP; this will greatly expand participation. Consequently, significantly more teachers will be involved in teaching the MYP in all three schools.

\section{The Metropolitan Nashville Public Schools, Tennessee}

Metropolitan Nashville Public Schools (MNPS) is a diverse system which resulted from the merger of the city and county systems in 1962. MNPS serves more than 76,000 students in 139 schools (72 elementary schools, 34 middle schools, 21 high schools, 7 special schools and 5 charter schools). The racial composition of MNPS is as follows: 46.5\% Black; 33.1\% White; 16.2\% Hispanic; 3.8\% Asian; .14\% Indian; and .11\% Pacific Islander.

Dr. Jesse Register, the Director of Schools, was appointed by the nine member school board to lead the district in January, 2009. He is a veteran educator with experience as a superintendent in Chattanooga and two districts in North Carolina. Register is operating under a performance contract and the threat of a mayoral take-over of the system if goals aren't met. MNPS operates under a seven-year strategic plan that was adopted in 2007.

Three high schools in MNPS offer the IB program, and two of them are in the Access Project-Hillsboro High School and Hunters Lane Comprehensive High School. The 
district coordinator for IB programs also served as the DP coordinator at Hunters Lane Comprehensive High School when their DP was authorized in 2001. It is suggested that students who wish to participate in the MYP complete advanced mathematics and language arts in middle school and have a strong academic background; however, in both pilot schools, principals and teachers indicated that they encourage any student who wants to try MYP coursework to begin the program in the ninth grade. Admission to the DP requires a strong academic record with possible Advanced Placement work at the ninth or tenth grades; Honors English I and Honors English II credits; and two years of either Spanish or French.

During Year 2, the district coordinator led efforts to obtain authorization for several PYP programs and to expand the MYP programs to several middle schools. She is housed in the Instructional Division at the district office and reports to the Director of High Schools. The Director of High Schools was a principal at a school with an IB program in Florida and his focus is on development of Small Learning Communities (SLCS). The SLC focus, as it is playing out in the schools, may not be entirely compatible with the MYP, and recent student alignment into academies does not parallel MYP or DP programming. There is some sentiment that IB will be marginalized when the career-focused academies are fully implemented. In addition, Hunters Lane, which will not offer MYP programming for all students, has capped MYP participation to allow for other programming. In Year 1, a local newspaper article called public attention to the relative cost of IB and argued that the return on the investment was low as evidenced by how few Diplomas were being earned.

Changes from Year 1 to Year 2 include the following: there is a new principal at Hillsboro HS and in February, 2011, a highly controversial move, the DP coordinator was relieved of her duties as coordinator and the district coordinator served as the DP coordinator for the remainder of the school year, spending some time each week on campus. All ninth and tenth grade students participated in the MYP and a different Assistant Principal supported the program. There were few changes at Hunters Lane HS except for a large number of new teachers in the MYP. In Year 3, there is a new MYP coordinator and new DP coordinator. At Hunters Lane, both the MYP and DP coordinators have been relieved of their duties and an Assistant Principal will serve as IB coordinator for the school, and a teacher will assume the responsibilities for MYP coordination. At the district level, a new IB Coach has been hired.

\section{The School District of Palm Beach County, Florida}

There are 187 schools in Palm Beach County and 172,664 students; it is the fifth largest school district in Florida and the eleventh largest school district in the nation. Leadership in Palm Beach County was stable as a former Palm Beach County high school principal and school board member, Dr. Art Johnson, served as superintendent for ten years before resigning in February, 2011. Palm Beach County's student population increased slightly this past year.

The IB programs are administered by the Office of Choice Programs. The district has 155 choice programs which include magnets, career academies and choice schools, and enroll 32,000 students. There is an application process for the Choice Programs, including IB programs, and the applications are screened centrally. Current application criteria are as follows: 3.0 Academic GPA, Algebra I, and Spanish or French for High 
School credit. All three pilot schools indicated that they recruit promising candidates who do not meet all of these requirements from among the students who attend their school because they live within the attendance boundaries. The district IB coordinator reports to the Director of Choice Programs who was new to the position this school year.

Changes from Year 1 to Year 2 included the resignation of the superintendent in February, 2011. An interim superintendent, Mr. Bill Malone, a non-educator, former civil servant from the community, was named to serve approximately one year. In Year 2, the responsibility for IB implementation at Pahokee Middle-High School was shared by the middle school principal, who was new to the position, and the high school principal. Changes in Year 3 include a new principal at Atlantic High School and a new superintendent anticipated in the district sometime in the spring of 2012.

\section{The Eight High Schools}

Table 1 below displays basic information about the three districts and the eight high schools. Seven of the schools are large with sizable numbers of students of color and students receiving free and reduced lunch. All of the schools are majority minority, with Pahokee High School enrolling 98 percent minority students. Yet there are distinct differences in school cultures and populations across the eight schools. For example, Pahokee Middle-Senior High School, while part of a large, urban district, is located on the outer edge of the county and is rural; it is also smaller than the other schools in the project with 900 middle and high school students. Meade High School is located on a military base. Forest Hill High School is perhaps the most urban school of the eight, located on a busy artery off I-95.

The schools also vary widely in the size of their MYP programs, ranging from 114 students to 565 . The composition of the MYP programs also varies widely, with minority enrollments ranging from 28.5 percent to 98.8 percent. A slightly greater range is seen in the Diploma Programme. All of the schools except Hunter's Lane HS and Pahokee HS have much smaller percentages of minority students in the DP than in their general population.

All eight high schools face challenges in addition to creating more inclusive IB programming. Probably the single factor they all have in common is the very real pressure of state assessments and the focus on student performance on these highstakes tests. They all have experienced decreases in budget which will limit the amount of time available to collaborate and the number of teachers. 
Table 1

Characteristics of the Participating High Schools

2010-2011

\begin{tabular}{|c|c|c|c|c|c|c|c|c|}
\hline \multirow[t]{2}{*}{ Indicators } & \multicolumn{3}{|c|}{ Anne Arundel County } & \multicolumn{2}{|c|}{ Nashville } & \multicolumn{3}{|c|}{ Palm Beach } \\
\hline & Annapolis & Meade & $\begin{array}{l}\text { Old } \\
\text { Mill }\end{array}$ & Hillsboro & $\begin{array}{l}\text { Hunters } \\
\text { Lane }\end{array}$ & Atlantic & $\begin{array}{c}\text { Forest } \\
\text { Hill }\end{array}$ & Pahokee \\
\hline Enrollment & 1544 & 2285 & 2266 & 1178 & 1643 & 2132 & 1795 & 975 \\
\hline $\begin{array}{l}\text { \% Minority } \\
\text { Enrollment }\end{array}$ & 63 & 77 & 52 & 62.5 & 77 & 74.4 & 81 & 98 \\
\hline$\%$ Free Lunch & 41.0 & 35.0 & 27.0 & 56.5 & 66.8 & 58.0 & 56.0 & 90.0 \\
\hline MYP Enrollment & 218 & 205 & 176 & 565 & 114 & 272 & 147 & 260 \\
\hline $\begin{array}{l}\text { \% MYP Minority } \\
\text { Enrollment* }\end{array}$ & 28.5 & 65.0 & 38.1 & 65.6 & 67.6 & 47.1 & 75.6 & 98.8 \\
\hline$\%$ MYP Free Lunch & 7.0 & $\begin{array}{l}\text { No } \\
\text { data }\end{array}$ & 13.6 & 42.7 & 74.6 & 22.3 & 56.3 & 86.9 \\
\hline DP Enrollment & 139 & 103 & 158 & 89 & 49 & 246 & 40 & 47 \\
\hline $\begin{array}{l}\text { \%DP } \\
\text { Minority Enrollment* }\end{array}$ & 22.3 & 59.3 & 36.8 & 31.5 & 77.5 & 46.0 & 67.5 & 95.8 \\
\hline $\begin{array}{l}\text { \% DP Free } \\
\text { Lunch }\end{array}$ & 5.0 & $\begin{array}{c}\text { No } \\
\text { data }\end{array}$ & 5.1 & 13.8 & 79.6 & 22.0 & 42.1 & 91.5 \\
\hline
\end{tabular}

Note: Information contained in this chart is from the following sources: federal, state, district and school websites; interviews; and self-reports by school principals, DP, and MYP school coordinators and IB district coordinators. Anne Arundel County is currently changing data systems and FRL data are not available.

*Minority enrollment includes all non-white enrollment: Asian; Black; and Hispanic.

\section{Project Evaluation Activities}

The IB contracted with the Consortium for Policy Research in Education (CPRE) at Teachers College, Columbia University to provide documentation and formative evaluation of the progress and impact of the IB Access Project. CPRE was also asked to provide some of the technical assistance for the project. In order to address this potential conflict of interest, CPRE has kept the two activities separate by utilizing different staff; the evaluation has been conducted by an external consultant, Gail Gerry, who is an experienced project evaluator and managed by the Director of CPRE, Tom Corcoran.

Documentation methods in Year 2 included a teacher survey, website and document reviews; student participation analysis; interviews of district and school employees; interviews of IB employees and project consultants and CPRE technical assisters; observations of school-based and district-based professional development and support sessions and Summer Institutes; and IB meetings with key project participants.

Below is a table depicting the numbers of interviews conducted with teachers and administrators and the survey responses from teachers by school district. District interviews were conducted January-February, 2011, with all but one of the 56 interviews occurring in person. In the communication about scheduling the interviews, district and school coordinators were asked to select teachers who had experience with the onsite professional learning activities and with the IB-developed tools, especially the website. 
IB staff, IB contractor and CPRE technical assister interviews were conducted primarily by phone, with one exception, during the spring and summer, 2011. Teacher surveys were completed during the first day of the two-day Summer Institutes held in June, 2011. Therefore, there is a risk that the survey results may be somewhat biased as they reflect the opinions of the teachers who participated in the professional development and who might be expected to have somewhat more positive views of the project and the recommended practices than teachers who chose not to participate in the Summer Institute. In any case, the reader should be aware that while the majority of the teachers involved in the project completed surveys in almost all of the sites, the sample sizes are small for each school and responses of a few individuals can create distortions in the overall patterns. Interviews were coded and analyzed for patterns; quotes found later in the report are indicative of the responses. Teacher surveys were coded and analyzed and tables in the report highlight particularly interesting and important findings.

Table 2

Interviews and Surveys by Site

2010-11

\begin{tabular}{lcc}
\hline Districts/ IB Staff and Consultants & $\begin{array}{c}\text { Number of Interviews } \\
\text { Conducted }\end{array}$ & $\begin{array}{c}\text { Number of Survey } \\
\text { Responses }\end{array}$ \\
\hline Anne Arundel & 20 & 29 \\
Metro Nashville & 17 & 27 \\
Palm Beach & 19 & 20 \\
IB Staff and Consultants and CPRE & & NA \\
Technical Assts. & 7 & \\
\hline
\end{tabular}

In addition, CPRE evaluators have participated in IB conference calls and have augmented formal interviews with informal conversations and emails with IB employees, project consultants and school and district project participants to help better understand project planning and implementation.

Participation numbers, interview protocols, and the survey instrument are in Appendices $A, B$, and $C$, respectively.

To determine the degree to which progress has been made toward the four project goals, analyses of the data were conducted in six major areas: beliefs about students, changes teaching practices; resources and support; communities of practice; student success and underrepresented students; and the theory of change.

\section{Beliefs about Students and the IB}

One of the major obstacles the Access Project has had to overcome is teacher beliefs about the type of students who might succeed in the MYP and DP programs. Teachers were surveyed to determine the degree to which they believed students could be successful in rigorous coursework. Table 3 below displays their responses. These same questions were asked on the Year 1 survey and while there is some fluctuation in the responses, the overall patterns of response are similar in Year 2. 
Overall teachers seem to believe that students are capable of doing the work demanded by the MYP. However, they differ about the degree to which their students take responsibility for their work - there seems to be considerable doubt about this in at least three of the eight schools - and the relative importance of effort versus ability - half of the respondents in two schools believe effort is not sufficient. And, about half of the teachers in four schools report that they do not use the same criteria to assess all students; so their "standards in practice" vary.

Table 3

Year 2 Teachers' Expectations

(Percentage Agreeing with the Statements)

\begin{tabular}{|c|c|c|c|c|c|c|c|c|}
\hline \multirow[t]{2}{*}{ Indicators } & \multicolumn{3}{|c|}{ Anne Arundel County } & \multicolumn{2}{|c|}{ Nashville } & \multicolumn{3}{|c|}{ Palm Beach } \\
\hline & Annapolis & Meade & $\begin{array}{l}\text { Old } \\
\text { Mill }\end{array}$ & Hillsboro & $\begin{array}{l}\text { Hunters } \\
\text { Lane }\end{array}$ & Atlantic & $\begin{array}{l}\text { Forest } \\
\text { Hill }\end{array}$ & Pahokee \\
\hline $\begin{array}{l}\text { With adequate time, } \\
\text { students can master } \\
\text { knowledge and skills } \\
\text { expected of them. }\end{array}$ & 100 & 100 & 100 & 100 & 100 & 100 & 100 & 100 \\
\hline $\begin{array}{l}\text { Students are capable } \\
\text { of learning the } \\
\text { material. }\end{array}$ & 88 & 86 & 60 & 90 & 100 & 71 & 79 & 100 \\
\hline $\begin{array}{l}\text { Students take } \\
\text { responsibility for work. }\end{array}$ & 52 & 29 & 80 & 65 & 57 & 86 & 100 & 67 \\
\hline $\begin{array}{l}\text { Student success is } \\
\text { based on their effort. }\end{array}$ & 71 & 71 & 60 & 75 & 100 & 71 & 43 & 50 \\
\hline $\begin{array}{l}\text { I use the same criteria } \\
\text { to assess all students. }\end{array}$ & 59 & 86 & 60 & 55 & 57 & 86 & 43 & 100 \\
\hline $\begin{array}{l}\text { Students can work in } \\
\text { groups without close } \\
\text { supervision. }\end{array}$ & 47 & 86 & 100 & 50 & 57 & 100 & 86 & 50 \\
\hline $\begin{array}{l}\text { The IB MYP program } \\
\text { has the potential to } \\
\text { benefit my students. }\end{array}$ & 100 & 100 & 100 & 100 & 100 & 100 & 100 & 100 \\
\hline $\begin{array}{l}\text { I believe that most of } \\
\text { the students in the IB } \\
\text { MYP program should } \\
\text { move into the IB } \\
\text { Diploma program. }\end{array}$ & 65 & 57 & 40 & 65 & 71 & 71 & 29 & 67 \\
\hline
\end{tabular}

The data displayed in Table 3 also indicates that all of the respondents believe that their students can benefit from the MYP program which is a strong endorsement of the program. However, there are differences of opinion about the desirability of most MYP students moving into the DP program. While two-thirds of the respondents support this view in five of the schools, teachers in the other three schools are more divided on this issue. 
"I believe with the right teachers and the right supports any student can be successful in IB."

MYP Coordinator

"MYP is good instruction. Period. All students should be able to do it." MYP Language A Teacher

We also examined these responses by the years of experience of the respondents, by the amount of IB training they had received, and by their teaching assignments. We found no significant differences in the teachers' responses to the items in Table 3 by years of teaching experience, the amount of IB training that they had received, or their teaching assignments. The differences seen in the data appear to be related to the professional culture of the school and not to the characteristics of the teachers.

\section{Teaching Practices}

Teachers and other school staff believe that improved teaching strategies can yield better learning for all students and especially students who have historically not participated in the program. Overwhelmingly, changes in instructional and assessment practices are the two areas respondents report are making a difference in student learning.

"Extending student answers and asking probing questions and engaging students all the time. Moving the learning along in terms of content."

District IB Coordinator

"Teaching bell to bell. Being focused on student inquiry and higher level thinking. That is the key to learning."

MYP Science Teacher

"If teachers understand IB assessment, they will be able to design and deliver instruction that will get the students there. The assessments are the drivers."

IB Staff Member

Teachers new to teaching (first three years) and/or new to teaching in the MYP recognized the importance of planning and delivering rigorous lessons but reported feeling overwhelmed by "all the pieces."

"I haven't been to training yet and I am not sure how to do the program; some of the veterans say 'it's just good teaching,' but there are things like areas of interaction that I don't get."

MYP Language A Teacher

"I wasn't in the cohort last year and I feel like I still don't grasp what MYP is. I jumped into this. I have learned myself." 
Similar to teacher responses we received in Year 1, we heard lots of concern about lack of time to plan and prepare lessons and limited opportunities to collaborate with other teachers. When teachers shared planning time during the day with other teachers who either taught the same students or who taught the same content they reported that it significantly helped them in lesson planning and design.

"I have five preps; that is ridiculous. I can't do the kind of planning and preparation that is necessary to meet the needs of the students, especially those who are struggling."

MYP Language B Teacher

"This year I have my planning period with another English teacher and we have found that we can really help each other think through what the teaching will look like. It is a real benefit to have someone to bounce ideas off of."

MYP Language A Teacher

As in Year 1, teachers were surveyed in the summer of Year 2 implementation on how prepared they felt they were to use various "best" instructional practices and the degree to which they used these instructional practices. Table 4 indicates their perceived preparedness and Table 5 shows the degree to which they indicated they use these "best" practices. The list of "best practices" is based on reviews of the research literature on instructional practices conducted by Hattie (2009) and by Corcoran and Silander (2008). Best practices are those found to have effect sizes of 0.50 or higher across all or almost all of the studies that examined their relationship to student learning. In most cases, these practices were effective in all curricular areas, although their form sometimes varied slightly across content domains. This means that consistent and effective use of any one of these practices raised student learning by at least a half of a standard deviation. The classroom practices that fell into this category included:

1. Lesson and unit design (as defined by Madeline Hunter)

2. Selection of tasks with appropriate cognitive demand

3. Use of well-structured student groups (cooperative or team learning) in the classroom

4. Use of formative assessment/adaptive instruction strategies

5. Provision of regular feedback

6. Stimulating student-centered discussion (within and across groups)

These practices are described briefly in Corcoran and Silander (2008) and in more detail in the forthcoming publication by Corcoran, Silander, and Stroud. In the latter piece, they are referred to as high-impact practices. The use of high-impact strategies will be addressed in the next section when discussing on-site professional learning, as much of the on-site support focused on helping teachers understand and implement these strategies. 
Table 4

Teacher Preparedness to Use Good Teaching Practices

Year 2

(Percent Responding Fairly or Well Prepared)

Indicators

Anne Arundel County

Nashville

Palm Beach

\begin{tabular}{|c|c|c|c|c|c|c|c|c|}
\hline & Annapolis & Meade & $\begin{array}{l}\text { Old } \\
\text { Mill }\end{array}$ & Hillsboro & $\begin{array}{l}\text { Hunters } \\
\text { Lane }\end{array}$ & Atlantic & $\begin{array}{c}\text { Forest } \\
\text { Hill }\end{array}$ & Pahokee \\
\hline $\begin{array}{l}\text { Use student } \\
\text { work to plan }\end{array}$ & 88 & 71 & 100 & 75 & 71 & 100 & 71 & 67 \\
\hline Use rubrics & 100 & 71 & 100 & 90 & 100 & 86 & 100 & 100 \\
\hline $\begin{array}{l}\text { Organize a } \\
\text { standards- } \\
\text { based class }\end{array}$ & 58 & 100 & 80 & 70 & 71 & 86 & 100 & 100 \\
\hline Use inquiry & 82 & 86 & 100 & 60 & 71 & 86 & 86 & 100 \\
\hline $\begin{array}{l}\text { Use student } \\
\text { data to plan }\end{array}$ & 82 & 71 & 100 & 75 & 71 & 86 & 86 & 83 \\
\hline $\begin{array}{l}\text { Use criterion- } \\
\text { related } \\
\text { assessments }\end{array}$ & 71 & 86 & 100 & 50 & 57 & 43 & 71 & 50 \\
\hline $\begin{array}{l}\text { Use lesson } \\
\text { design }\end{array}$ & 88 & 100 & 100 & 70 & 71 & 71 & 100 & 100 \\
\hline $\begin{array}{l}\text { Use student } \\
\text { teams }\end{array}$ & 59 & 86 & 60 & 60 & 86 & 71 & 71 & 83 \\
\hline $\begin{array}{l}\text { Emphasize } \\
\text { high-demand } \\
\text { tasks }\end{array}$ & 100 & 86 & 100 & 70 & 71 & 57 & 100 & 100 \\
\hline $\begin{array}{l}\text { Emphasize } \\
\text { student } \\
\text { discussion }\end{array}$ & 88 & 100 & 80 & 70 & 71 & 100 & 86 & 100 \\
\hline $\begin{array}{l}\text { Use formative } \\
\text { assessment } \\
\text { strategies }\end{array}$ & 94 & 86 & 100 & 65 & 71 & 71 & 100 & 100 \\
\hline $\begin{array}{l}\text { Provide } \\
\text { students with } \\
\text { feedback }\end{array}$ & 94 & 71 & 100 & 60 & 43 & 71 & 100 & 83 \\
\hline $\begin{array}{l}\text { Use of unit } \\
\text { questions }\end{array}$ & 94 & 71 & 100 & 70 & 71 & 57 & 100 & 67 \\
\hline
\end{tabular}

This core set of practices was used to generate items for the teachers' survey and were referred to in the survey as "best" practices as teachers are familiar with that language. They were described in the survey in very general terms in order to determine if teachers were using any practices that were similar to those we had in mind. We also added other practices (use of rubrics, use of student work to plan, etc.) that are associated with standards and considered to be good practices even if there is not always research evidence showing high impact on learning. 
Teachers' sense of preparedness improved significantly from Year 1 to Year 2. Whether this is due to the provision of technical assistance or simply increased familiarity with the practices or more awareness of the expectations of the IB project is not clear, but for ten of the thirteen practices listed in Table 4, there were significant increases in the numbers of teachers who reported they felt prepared to use the practices. The largest gains in preparedness were for using rubrics, using inquiry, using lesson design, using student teams, and emphasizing high-demand tasks. The results showed no change for three of the items - organizing a standards-based classroom, using student data to plan, and using criterion-referenced assessments.

The data in Table 4 suggest that the vast majority of teachers feel prepared to use the high-impact practices. Large numbers of teachers in several schools indicated they were not well prepared to design lessons or to use of student teams. Criterionreferenced assessment was an area of weak preparation in four of the schools.

Table 5

Frequency of Use of Good Teaching Practices

Year 2

(Percent Responding Often or Always)

\begin{tabular}{|c|c|c|c|c|c|c|c|c|}
\hline \multirow[t]{2}{*}{ Indicators } & \multicolumn{3}{|c|}{ Anne Arundel County } & \multicolumn{2}{|c|}{ Nashville } & \multicolumn{3}{|c|}{ Palm Beach } \\
\hline & Annapolis & Meade & $\begin{array}{l}\text { Old } \\
\text { Mill }\end{array}$ & Hillsboro & $\begin{array}{c}\text { Hunters } \\
\text { Lane }\end{array}$ & Atlantic & $\begin{array}{c}\text { Forest } \\
\text { Hill }\end{array}$ & Pahokee \\
\hline $\mathbf{N}$ & 17 & 7 & 5 & 20 & 7 & 7 & 7 & 6 \\
\hline $\begin{array}{l}\text { Organize } \\
\text { standards- } \\
\text { based classes }\end{array}$ & 94 & 100 & 80 & 80 & 57 & 100 & 100 & 100 \\
\hline Use rubrics & 88 & 43 & 100 & 60 & 57 & 57 & 86 & 50 \\
\hline Use inquiry & 71 & 86 & 80 & 55 & 43 & 43 & 57 & 50 \\
\hline $\begin{array}{l}\text { Use student } \\
\text { work to plan }\end{array}$ & 76 & 29 & 100 & 55 & 71 & 43 & 43 & 17 \\
\hline $\begin{array}{l}\text { Use student } \\
\text { data to plan }\end{array}$ & 53 & 57 & 100 & 60 & 71 & 57 & 57 & 50 \\
\hline $\begin{array}{l}\text { Use criterion- } \\
\text { related } \\
\text { assessments }\end{array}$ & 76 & 57 & 80 & 45 & 43 & 57 & 71 & 50 \\
\hline $\begin{array}{l}\text { Use lesson } \\
\text { design }\end{array}$ & 88 & 86 & 80 & 50 & 57 & 43 & 86 & 50 \\
\hline $\begin{array}{l}\text { Emphasize } \\
\text { student } \\
\text { discussion }\end{array}$ & 83 & 71 & 80 & 65 & 71 & 43 & 86 & 67 \\
\hline $\begin{array}{l}\text { Use student } \\
\text { teams }\end{array}$ & 59 & 86 & 60 & 30 & 43 & 57 & 57 & 33 \\
\hline $\begin{array}{l}\text { Use formative } \\
\text { assessment } \\
\text { strategies }\end{array}$ & 82 & 86 & 100 & 65 & 71 & 57 & 71 & 83 \\
\hline $\begin{array}{l}\text { Use high } \\
\text { cognitive } \\
\text { demand lessons }\end{array}$ & 88 & 86 & 100 & 70 & 57 & 86 & 71 & 50 \\
\hline $\begin{array}{l}\text { Provide } \\
\text { students with } \\
\text { feedback }\end{array}$ & 88 & 57 & 100 & 50 & 29 & 71 & 86 & 50 \\
\hline
\end{tabular}


In Table 5, above, we report on the frequency of use of these same instructional practices. Not unexpectedly, the teachers report frequent use of many of the practices in most schools; survey data almost always over-state the use of good practices. However, what is surprising is the level of variation in the responses across schools. Frequent use of these practices is reported by half or fewer of the respondents in 24 of the 96 cells in the table or 25 percent of the instances. The lowest response rates are from Pahokee HS.

\section{Preparedness and Use of Instructional Practices}

We examined the relationship between teachers' assessments of their preparedness and their reported use of practices. These data are reported in Table 6 . The results show strong links between feelings of preparedness and reported use of practices.

Table 6

Correlations between Preparedness and Use Of Instructional Practices

$\mathrm{N}=74$

\begin{tabular}{lc}
\hline \multicolumn{1}{c}{ Practice } & $\begin{array}{c}\text { Correlation Coefficient } \\
\text { Spearman's rho }\end{array}$ \\
\hline Use student work to plan & .531 \\
Use rubrics & .628 \\
Organize a standards-based classroom & .368 \\
Use inquiry & .663 \\
Use student data to plan & .549 \\
Use criterion-referenced assessments & .626 \\
Use lesson design & .633 \\
Use learning teams & .682 \\
Emphasize high demand tasks & .663 \\
Emphasize student discussion & .560 \\
Use formative assessment & .697 \\
Provide feedback to students & .732 \\
\hline
\end{tabular}

All of the correlations shown in Table 6 are positive and all but one -organizing the standards-based classroom-are significant at the .0001 level. While these correlations do not "prove" there is a link between training and use, they do provide strong evidence that there may be such a link. It is particularly encouraging that some of the high-impact practices that have been emphasized in the Summer Institutes such as the use of rubrics, use of teams, attention to lesson design and high demand tasks, formative assessment, and feedback show particularly high correlations. 


\section{Preparedness and Use of IB Practices and Tools}

While the respondents feel confident about their general preparedness to teach, they are less confident about their mastery of specific IB tools and practices. Table 7 shows significant numbers of teachers are somewhat uncertain about their command of the Areas of Interaction and the Learner Profile. The vast majority are more confident about their ability to use the MYP Unit Planner and emphasize international-mindedness.

Table 7

Teachers' Preparedness to Use IB Practices and Tools

Year 2

(Percent Responding Fairly Well or Very Well Prepared)

\begin{tabular}{lcccccccc}
\hline Indicators & \multicolumn{2}{c}{ Anne Arundel County } & \multicolumn{2}{c}{ Nashville } & \multicolumn{3}{c}{ Palm Beach } \\
\hline & Annapolis & Meade & $\begin{array}{c}\text { Old } \\
\text { Mill }\end{array}$ & Hillsboro & $\begin{array}{c}\text { Hunters } \\
\text { Lane }\end{array}$ & Atlantic & $\begin{array}{c}\text { Forest } \\
\text { Hill }\end{array}$ & Pahokee \\
\hline $\begin{array}{l}\text { Use Areas of } \\
\text { Interaction }\end{array}$ & 71 & 57 & 40 & 35 & 29 & 43 & 51 & 83 \\
$\begin{array}{l}\text { Use the } \\
\text { Learner Profile }\end{array}$ & 71 & 86 & 100 & 55 & 57 & 57 & 43 & 50 \\
$\begin{array}{l}\text { Use the MYP } \\
\begin{array}{l}\text { Unit Planner } \\
\text { Include } \\
\text { international- } \\
\text { mindedness in } \\
\text { lessons }\end{array}\end{array}$ & 71 & 71 & 100 & 50 & 71 & 71 & 71 & 83 \\
\hline
\end{tabular}

Table 8 below shows a wide range of responses in teacher use and practices with the use of the MYP Unit Planner generally being the least used practice and internationalmindedness in lessons being the most used practice. The range and variation in responses, even within a district, suggests little consistency in daily practice in MYP classrooms and rather limited use of some of the key tools. In fact, half or fewer of the respondents reported low use of these tools in 19 of the 32 cells or 59 percent of the instances.

Table 8 Teachers' Reported Use of IB Practices and Tools

Year 2

(Percent Responding Often or Always)

\begin{tabular}{lcccccccc}
\hline \multicolumn{1}{c}{ Indicators } & \multicolumn{2}{c}{ Anne Arundel County } & \multicolumn{2}{c}{ Nashville } & \multicolumn{3}{c}{ Palm Beach } \\
\hline & Annapolis & Meade & $\begin{array}{c}\text { Old } \\
\text { Mill }\end{array}$ & Hillsboro & $\begin{array}{c}\text { Hunters } \\
\text { Lane }\end{array}$ & Atlantic & $\begin{array}{c}\text { Forest } \\
\text { Hill }\end{array}$ & Pahokee \\
\hline $\begin{array}{l}\text { Use Areas of } \\
\text { Interaction }\end{array}$ & 59 & 57 & 40 & 10 & 14 & 57 & 43 & 33 \\
$\begin{array}{l}\text { Use the } \\
\text { Learner }\end{array}$ & 53 & 71 & 60 & 10 & 14 & 29 & 42 & 33 \\
$\begin{array}{l}\text { Profile } \\
\text { Use the MYP }\end{array}$ & 59 & 29 & 40 & 0 & 14 & 14 & 29 & 33 \\
$\begin{array}{l}\text { Unit Planner } \\
\text { Include } \\
\text { international- } \\
\text { mindedness } \\
\text { in lessons }\end{array}$ & 65 & 71 & 60 & 50 & 43 & 29 & 71 & 50 \\
\hline
\end{tabular}




\section{Relationship between Preparedness and Use}

As we did with the high-impact practices, we examined the relationship between teachers' assessments of their preparedness and their reported use of IB practices. These data are reported in Table 9. The results show strong links between feelings of preparedness and reported use of practices.

Table 9

Correlations Between Preparedness and Use

Of IB Practices

$\mathrm{N}=74$

\begin{tabular}{lc}
\hline \multicolumn{1}{c}{ Practice } & $\begin{array}{c}\text { Correlation Coefficient } \\
\text { Spearman's rho }\end{array}$ \\
\hline Use of Areas of Interaction & .677 \\
Use of the Learner Profile & .735 \\
Use of the MYP Planner & .557 \\
Include international mindedness in & .630 \\
lessons & \\
\hline
\end{tabular}

The MYP Planner which was the least used of the four IB practices also shows the weakest link between feeling prepared and actually using the practice.

\section{Resources and Support}

In this section, we report on the new resources and support provided by IB. The IB Access Project's theory of change is predicated on the design and execution of these two major strategies for teachers to help them meet the project's goals of providing greater access and increased success for historically underrepresented students. The new resources include curricular units, assessment resources, online professional development and online mentoring. The resource development work has been led by staff at the IB with the assistance of contractors from Triple A Learning and from Harvard Project Zero. Year 2 resource development and refinement occurred in the following areas: the Bridge to Success website; new MYP units; the assessment task bank; and provision of online professional support which included blended professional development workshops, online workshops, and online mentoring. The on-site support for teachers includes the workshops and instructional coaching provided by CPRE staff and similar support provided by IB consultants focused on the use of new tools and materials.

\section{Resources}

The Bridge to Success website housing the new resources and tools was launched in October, 2010. Since the initial launch, the website has been changed considerably in appearance and in its usability, and the tools and resources have been expanded significantly and refined. The IB staff have conducted a number of meetings, school site visits, phone calls and emails to elicit user feedback and suggestions, and, as a result, the status of these resources at the end of the year was quite different than what teachers and school and district staff had available to them in the winter and spring. 
Bridge to Success website. The goal was to design a website that was much more user-friendly than the Online Curriculum Centre, the IB website that houses tools and resources for teachers. Table 10 shows how survey respondents viewed the website and the materials and tools it provided. The survey data show teachers' use of the new website varied. However, the percentages of respondents who felt that the website might be useful, even if they were not using it at present, were high in seven of the eight schools. This suggests that there are potential users who have not yet been engaged.

Table 10

Use and Utility of the Bridge to Success Website by School Year 2

(Percent Sometime or Often Or Somewhat, Very, or Extremely Useful)

\begin{tabular}{|c|c|c|c|c|c|c|c|c|}
\hline \multirow[t]{2}{*}{ Indicators } & \multicolumn{3}{|c|}{ Anne Arundel County } & \multicolumn{2}{|c|}{ Nashville } & \multicolumn{3}{|c|}{ Palm Beach } \\
\hline & $\begin{array}{c}\text { Annapolis } \\
\mathrm{N}=17\end{array}$ & $\begin{array}{c}\text { Meade } \\
\mathrm{N}=7\end{array}$ & $\begin{array}{l}\text { Old } \\
\text { Mill } \\
\mathrm{N}=5\end{array}$ & $\begin{array}{l}\text { Hillsboro } \\
\mathrm{N}=19\end{array}$ & $\begin{array}{c}\text { Hunters } \\
\text { Lane } \\
\mathrm{N}=7\end{array}$ & $\begin{array}{c}\text { Atlantic } \\
\mathrm{N}=7\end{array}$ & $\begin{array}{c}\text { Forest } \\
\text { Hill } \\
\mathrm{N}=7\end{array}$ & $\begin{array}{c}\text { Pahokee } \\
\mathrm{N}=5\end{array}$ \\
\hline $\begin{array}{l}\text { Use of the } \\
\text { Bridge to } \\
\text { Success } \\
\text { Website }\end{array}$ & 0 & 29 & 40 & 25 & 29 & 0 & 14 & 0 \\
\hline $\begin{array}{l}\text { Utility of the } \\
\text { Bridge to } \\
\text { Success } \\
\text { Website }\end{array}$ & 58 & 57 & 80 & 35 & 14 & 43 & 43 & 83 \\
\hline
\end{tabular}

The interview data showed that teachers' perceptions of how easy the website was to use also varied.

"I find it easy to use. It is attractive."

MYP Coordinator

"They said it would be like Facebook. I am on Facebook all the time and let me tell you, it is NOTHING like Facebook."

MYP Language B Teacher

The survey data show variation in teachers' perceptions of the usefulness of the website, and the interview data was consistent with the survey. Of the 48 interview respondents who said they knew about the website, less than one-fourth reported that the website and the tools assisted them in MYP implementation.

"I went to the site and there was nothing there in my content. I checked back a couple of times because our coordinator told us we had to, but there is nothing new. I must admit, I don't plan to go back until maybe this summer when I have more time."

\section{MYP Science Teacher}

"We had someone come out to the school and show us how to get on, and then there were glitches with the passwords and signing up for things and it was too much bother. I haven't done anything with it and until someone else tells me that 
there are things on there that will help me in the classroom TOMORROW I don't intend to."

MYP Math Teacher

"They're paying us to go on so I log on. And I go in and look at the units and there is nothing there that I teach."

MYP Language B Teacher

A two-day forum was conducted in July, 2011 with representatives from all schools and school districts for the purpose of looking at patterns and challenges of website use and making recommendations to the developer and IB staff about ways to improve its functionality. It appears that the next iteration will be more intuitive and collaborative, allowing users to form groups around content, school or interest.

"Our idea is that it will be 'grab and go.' It will be easy for users to go in and get what they need."

IB Staff Member

MYP Units. The MYP Units were previously described as MYP Curriculum Units and before that as Course Companions or Curriculum Companions. The units were developed by veteran IB teachers and trainers and vetted by curriculum staff in Cardiff. Currently 22 units are in different stages of development; units have been developed in Language A, Language B, Biology, Chemistry and Mathematics. The units include overviews, standards and objectives, fundamental concepts, command terms, assessments and links to other materials. Although originally six to eight units were to be developed per subject area (Language A, Language B, Science and Mathematics), the current 22 are likely to be all that will be developed for the project.

Although the project plan called for a significant number of units to be available at the initial website launch, this did not happen. Consequently, the plan to "pilot" the units, gathering data from teachers in a systematic fashion, also has not happened.

Staff from Project Zero was asked to provide input about the key disciplinary ideas and the degree to which the units captured "the most important ideas" in a particular unit of study. This work was completed after the MYP units were developed, and the current plan is to post the ideas from Project Zero, which are contained in chapters by discipline, on the Bridge to Success website for teachers and coordinators to use to assist in use of the units and for teacher development of their own units. These chapters could serve as aides for teachers as they develop their own units or refine units that are posted on Bridge to Success. To date, none of the chapters have been posted on the Bridge to Success website.

Table 11 shows how frequently teachers accessed the units and their perceptions of their utility. The reader is reminded the number of respondents was small in six of the eight schools and the survey was completed by the teachers who came to the Summer Institutes. The data show that use of the units by the end of the 2010-11 school year was limited in five of the eight schools. But at Annapolis HS, Meade HS, Hunters Lane, and Pahokee, significant numbers of teachers reported using the units sometimes or often. And over 40 percent of the responding teachers at seven of the eight sites saw 
the units as useful. If the data are correct, many of these teachers had not used the units, but they saw their potential. Given the general experience with persuading teachers to use new curriculum materials voluntarily, it is not surprising that few had used the new material by the end of the 2010-2011 school year, but it is encouraging that so many teachers saw their potential utility.

Table 11

Use and Utility of the MYP Units by School

Year 2

(Percent of Respondents)

[Percentages in columns do not add to $100 \%$ due to missing responses]

\begin{tabular}{|c|c|c|c|c|c|c|c|c|}
\hline \multirow[t]{2}{*}{ Indicators } & \multicolumn{3}{|c|}{ Anne Arundel County } & \multicolumn{2}{|c|}{ Nashville } & \multicolumn{3}{|c|}{ Palm Beach } \\
\hline & $\begin{array}{l}\text { Annapolis } \\
\qquad \mathrm{N}=17\end{array}$ & $\begin{array}{l}\text { Meade } \\
\mathrm{N}=7\end{array}$ & $\begin{array}{c}\text { Old } \\
\text { Mill } \\
\mathrm{N}=5\end{array}$ & $\begin{array}{l}\text { Hillsboro } \\
\qquad \mathrm{N}=19\end{array}$ & $\begin{array}{c}\text { Hunters } \\
\text { Lane } \\
\mathrm{N}=7\end{array}$ & $\begin{array}{c}\text { Atlantic } \\
\mathrm{N}=7\end{array}$ & $\begin{array}{c}\begin{array}{c}\text { Forest } \\
\text { Hill } \\
\mathrm{N}=7\end{array} \\
\end{array}$ & $\begin{array}{c}\text { Pahokee } \\
\mathrm{N}=5\end{array}$ \\
\hline \multicolumn{9}{|l|}{$\begin{array}{l}\text { Use of the } \\
\text { MYP Units }\end{array}$} \\
\hline Never & 18 & 0 & 40 & 25 & 14 & 43 & 29 & 0 \\
\hline Rarely & 35 & 14 & 40 & 45 & 14 & 57 & 29 & 50 \\
\hline Sometimes & 12 & 71 & 20 & 20 & 43 & 0 & 29 & 17 \\
\hline Often & 29 & 14 & 0 & 5 & 14 & 0 & 0 & 17 \\
\hline \multicolumn{9}{|l|}{$\begin{array}{l}\text { Utility of the } \\
\text { MYP Units }\end{array}$} \\
\hline Not Useful & 0 & 0 & 0 & 0 & 0 & 0 & 0 & 0 \\
\hline Somewhat & 29 & 29 & 20 & 30 & 29 & 29 & 0 & 33 \\
\hline $\begin{array}{l}\text { Very or } \\
\text { Extremely } \\
\text { Useful }\end{array}$ & 18 & 57 & 40 & 40 & 57 & 43 & 57 & 50 \\
\hline $\begin{array}{l}\text { Not } \\
\text { applicable }\end{array}$ & 35 & 14 & 20 & 25 & 0 & 29 & 29 & 17 \\
\hline
\end{tabular}

In the interviews, teachers indicated that they would need some time to get into the units and see how they could use them.

"There is a lot of stuff there. I can't take the time while I am preparing to teach the next day to wade through everything. I am sure there is some good stuff. I just can't say with any certainty. Putting these materials out mid-year is just not good timing."

MYP Science Teacher

"I've gone on with the intention of using something. There are units for ninth grade but not tenth; Romeo and Juliet is there but I don't teach that."

Language A Teacher 
When it became clear that only a few teachers were accessing the units, the message was sent that there were a number of ways to use the units.

"We would really like you to go on the website and look at the units. There are a number of ways you can use them: you can teach them as a total, complete unit; you can teach part of them or adapt them; or you can use them as a model for units you are developing."

IB Staff Member (at a school meeting)

The Assessment Task Bank. The formative and summative assessment items that comprise the Assessment Task Bank were launched in the fall but in a very limited way. Table 12 displays the survey respondents' perceptions of the Assessment Task Bank. Teachers in only one school reported using the new resource regularly, but teachers in most of the schools saw its potential utility.

IB staff and consultants were delayed by the time required to obtain permission to post copyrighted material and users were frustrated by the limited number of items available so many were not using this tool.

"My teachers expected more. They said assessments would be up and they weren't. We were paying our teachers to go on and use this and they still weren't doing it."

MYP Coordinator

MYP assessments are difficult for teachers to develop so IB staff had every reason to believe that this would serve as an important resource. The assessments mirror DP assessments and are constructed so teachers can use them in a flexible manner. It is unclear how helpful these will be because very few of the teachers interviewed had used them.

"The MYP teachers at our school think they know how to do assessments. They think we are beyond that. In fact, we are not. But it is hard to convince them that we need to work on this."

MYP Coordinator 
Table 12

Use and Utility of the Assessment Task Bank

Year 2

(Percent of Respondents)

[Percentages in columns do not add to $100 \%$ due to missing responses]

\begin{tabular}{|c|c|c|c|c|c|c|c|c|}
\hline \multirow[t]{2}{*}{ Indicators } & \multicolumn{3}{|c|}{ Anne Arundel County } & \multicolumn{2}{|c|}{ Nashville } & \multicolumn{3}{|c|}{ Palm Beach } \\
\hline & $\begin{array}{l}\text { Annapolis } \\
\qquad N=17\end{array}$ & $\begin{array}{l}\text { Meade } \\
N=7\end{array}$ & $\begin{array}{c}\text { Old } \\
\text { Mill } \\
\mathrm{N}=5\end{array}$ & $\begin{array}{l}\text { Hillsboro } \\
\qquad N=19\end{array}$ & $\begin{array}{c}\text { Hunters } \\
\text { Lane } \\
\mathbf{N}=7\end{array}$ & $\begin{array}{c}\text { Atlantic } \\
\mathrm{N}=7\end{array}$ & $\begin{array}{c}\text { Forest } \\
\text { Hill } \\
N=7\end{array}$ & $\begin{array}{c}\text { Pahokee } \\
\text { N }=5\end{array}$ \\
\hline \multicolumn{9}{|l|}{$\begin{array}{l}\text { Use of the } \\
\text { Task Bank }\end{array}$} \\
\hline Never & 53 & 0 & 40 & 50 & 29 & 57 & 43 & 17 \\
\hline Rarely & 29 & 29 & 60 & 35 & 57 & 43 & 29 & 67 \\
\hline Sometimes & 6 & 43 & 0 & 5 & 0 & 0 & 14 & 0 \\
\hline Often & 0 & 29 & 0 & 0 & 0 & 0 & 0 & 0 \\
\hline \multicolumn{9}{|l|}{$\begin{array}{l}\text { Utility of the } \\
\text { Task Bank }\end{array}$} \\
\hline Not Useful & 6 & 0 & 0 & 10 & 14 & 0 & 0 & 0 \\
\hline Somewhat & 18 & 14 & 20 & 30 & 57 & 29 & 29 & 33 \\
\hline $\begin{array}{l}\text { Very or } \\
\text { Extremely } \\
\text { Useful }\end{array}$ & 35 & 85 & 80 & 15 & 0 & 29 & 0 & 34 \\
\hline $\begin{array}{c}\text { Not } \\
\text { applicable }\end{array}$ & 18 & 0 & 0 & 40 & 14 & 43 & 57 & 0 \\
\hline
\end{tabular}

Professional Development. The professional development that was provided in the online space during Year 2 evolved as a result of feedback from participants. IB staff made a serious effort to elicit feedback from both users and non-users and to respond to their concerns and needs. There were three types of online professional development envisioned: blended; all online; and mentoring, which originally was focused on assessment practices.

Blended professional development. The first round of workshops was conceived as semester-long "blended" workshops which would be comprised of an online component and a face-to-face component. These workshops were contentspecific (in Language A, Language B, Biology, and Math) and were offered focused on curriculum development or on assessment. More than in any other area of tool development the response was swift and clear: the initial offerings were not working for teachers. There was little interest in these workshops and sign-up was painfully slow. Many of the eight workshops were abandoned. Some were combined. A total of approximately 40 teachers signed up to participate and only some of them actually participated and even fewer finished the workshops. Some teachers reported that the workshop leader was not that effective or that they were the only ones participating. The concept of "blended" was confusing and the consultant sent to each site for Saturday sessions had few teachers attend. 
Table 13

Use and Utility of the Blended Workshops

Year 2

(Percent of Respondents)

[Percentages in columns may not add to $100 \%$ due to missing responses]

\begin{tabular}{|c|c|c|c|c|c|c|c|c|}
\hline \multirow[t]{2}{*}{ Indicators } & \multicolumn{3}{|c|}{ Anne Arundel County } & \multicolumn{2}{|c|}{ Nashville } & \multicolumn{3}{|c|}{ Palm Beach } \\
\hline & $\begin{array}{l}\text { Annapolis } \\
\qquad N=17\end{array}$ & $\begin{array}{l}\text { Meade } \\
N=7\end{array}$ & $\begin{array}{c}\text { Old } \\
\text { Mill } \\
\mathrm{N}=5\end{array}$ & $\begin{array}{l}\text { Hillsboro } \\
\qquad N=19\end{array}$ & $\begin{array}{c}\text { Hunters } \\
\text { Lane } \\
\mathbf{N}=7\end{array}$ & $\begin{array}{c}\text { Atlantic } \\
\qquad N=7\end{array}$ & $\begin{array}{c}\text { Forest } \\
\text { Hill } \\
N=7\end{array}$ & $\begin{array}{c}\text { Pahokee } \\
\mathrm{N}=5\end{array}$ \\
\hline $\begin{array}{l}\text { Use of the } \\
\text { Blended } \\
\text { Workshops } \\
\text { Never }\end{array}$ & 47 & 29 & 20 & 35 & 0 & 57 & 57 & 17 \\
\hline Rarely & 29 & 43 & 80 & 25 & 43 & 43 & 29 & 50 \\
\hline Sometimes & 18 & 29 & 0 & 35 & 43 & 0 & 0 & 17 \\
\hline Often & 0 & 0 & 0 & 5 & 14 & 0 & 0 & 17 \\
\hline $\begin{array}{l}\text { Utility of } \\
\text { the Blendec } \\
\text { PD } \\
\text { Not Useful }\end{array}$ & 6 & 29 & 0 & 5 & 14 & 14 & 0 & 0 \\
\hline Somewhat & 18 & 43 & 60 & 30 & 57 & 29 & 0 & 50 \\
\hline $\begin{array}{l}\text { Very or } \\
\text { Extremely } \\
\text { Useful }\end{array}$ & 47 & 14 & 20 & 25 & 0 & 14 & 29 & 17 \\
\hline $\begin{array}{l}\text { Not } \\
\text { applicable }\end{array}$ & 29 & 14 & 20 & 25 & 0 & 42 & 57 & 17 \\
\hline
\end{tabular}

The survey data presented in Table 13 show low levels of use in four schools and modest levels in two others, but also show that many teachers remain open to the potential utility of such workshops.

Overall, both the survey data and the interview data show that the blended workshops offered in 2010-11 did not meet teachers' needs and that the delivery system did not fit well with teachers' lives.

"I think I was the only one in my workshop who completed enough of the assignments to get the stipend. I think I might have been the only one who finished period. It was too much; it was painful. And it had nothing to do with helping us with this project."

MYP Language A Teacher

"The workshops were too long. Teachers need to be able to opt in and out. The timing was bad too. Teachers are too busy during the year to make that commitment."

District IB Coordinator

The workshops have been completely revamped and will be re-launched in the Fall of 2011. 
Online professional development. In the spring, two non-subject specific online workshops were launched: one focused on counseling MYP students and the other on working with MYP students with special needs including ELL students. Data collected by the IB indicate that two of 12 participants who signed up for the counseling workshop and six of 25 who signed up for the special needs workshop completed the program. Although the numbers who participated were quite small and those that completed the program even smaller, the responses to the IB survey were promising. Of the 14 teachers who completed the survey, 11 had never taught in the MYP before, and for 12 , this was their first IB training. Eleven felt the online workshop met their expectations and indicated that they would apply what they had learned.

There was no in-person component to these workshops and they were much shorter in duration. Data collected by the IB informed the revision of all workshops. One teacher commented on the survey:

"I learned so much about MYP and appreciate MYP's holistic rigorous approach. I'm rethinking how a unit gets designed. Tasks and rubric models were great and I'll be modeling mine from them. For future workshops consider adding a unit plan specifically for ELs [English Language Learners]."

Online mentoring. There was an attempt to provide mentoring in the Fall but there was no response from the teachers. Feedback was elicited and it was determined that instead of groups being formed to work on assessment, groups would be organized by school cohort or discipline. These mentoring groups were being formed during the time interviews were conducted in the schools. Although some teachers voiced trepidation based on earlier experiences with the website or blended workshops, there were also some educators who were excited about the possibility of connecting with a mentor and being in groups with colleagues. At the time of interviews, the impact of this new support was unclear.

Data gathered by IB show that the number of teachers who signed up or were signed up by their coordinators for the spring mentoring experience were Language A, 13; French, 4; Spanish, 10; Biology, 6; Chemistry, 9; and Math, 3.

IB requested information from the mentors to determine the degree of interaction that occurred between the mentors and teachers. The Language A mentors responded that of the 10 (Mentor's number does not match IB's numbers) who signed up only three had any interaction and only one had sustained interaction.

"...there were about ten teachers signed up for my Language $A$ Mentoredgroup. Of those ten, I had interactions with three of them. The interactions with the first two were just a few exchanges. I only had any sort of sustained interaction with one participant. I answered some questions he had about which criteria to use and I also gave him some feedback on units and assessments he posted through views. That interaction came toward the end of the year--April-June." 
No information was available about participant interaction in the other mentoring groups.

The survey data presented in Table 14 show that many of the respondents had not participated in the online mentoring but they had opinions about its utility anyway. These data are somewhat discouraging as the majorities of the respondents in seven of the eight schools either felt the mentoring was, or would be of limited value, or they felt it was not applicable to them. It seems clear that more active recruiting and stronger incentives will be needed to get teachers engaged in online.

Table 14

Use and Utility of the Online Mentoring

Year 2

(Percent of Respondents)

[Percentages in columns may not add to $100 \%$ due to missing responses]

\begin{tabular}{|c|c|c|c|c|c|c|c|c|}
\hline \multirow[t]{2}{*}{ Indicators } & \multicolumn{3}{|c|}{ Anne Arundel County } & \multicolumn{2}{|c|}{ Nashville } & \multicolumn{3}{|c|}{ Palm Beach } \\
\hline & $\begin{array}{l}\text { Annapolis } \\
\qquad N=17\end{array}$ & $\begin{array}{l}\text { Meade } \\
N=7\end{array}$ & $\begin{array}{c}\text { Old } \\
\text { Mill } \\
N=5\end{array}$ & $\begin{array}{l}\text { Hillsboro } \\
\qquad \begin{array}{l}N=19\end{array}\end{array}$ & $\begin{array}{c}\text { Hunters } \\
\text { Lane } \\
N=7\end{array}$ & $\begin{array}{c}\text { Atlantic } \\
\mathrm{N}=7\end{array}$ & $\begin{array}{c}\text { Forest } \\
\text { Hill } \\
N=7\end{array}$ & $\begin{array}{c}\text { Pahokee } \\
\mathrm{N}=5\end{array}$ \\
\hline \multicolumn{9}{|l|}{$\begin{array}{l}\text { Use of the } \\
\text { Online } \\
\text { Mentoring }\end{array}$} \\
\hline Never & 71 & 29 & 20 & 60 & 29 & 86 & 57 & 50 \\
\hline Rarely & 24 & 57 & 60 & 30 & 43 & 14 & 29 & 33 \\
\hline Sometimes & 0 & 14 & 20 & 5 & 14 & 0 & 0 & 0 \\
\hline Often & 0 & 0 & 0 & 0 & 0 & 0 & 0 & 0 \\
\hline \multicolumn{9}{|l|}{$\begin{array}{l}\text { Utility of the } \\
\text { Online } \\
\text { Mentoring }\end{array}$} \\
\hline Not Useful & 18 & 14 & 0 & 40 & 57 & 29 & 14 & 0 \\
\hline Somewhat & 18 & 43 & 40 & 10 & 14 & 14 & 14 & 33 \\
\hline $\begin{array}{l}\text { Very or } \\
\text { Extremely } \\
\text { Useful }\end{array}$ & 6 & 29 & 40 & 10 & 0 & 0 & 0 & 0 \\
\hline $\begin{array}{l}\text { Not } \\
\text { applicable }\end{array}$ & 59 & 14 & 20 & 35 & 14 & 57 & 57 & 33 \\
\hline
\end{tabular}

\section{On-site Support}

On-site support is the second major strategy to help teachers meet the project's goals and is being led by a CPRE staff member and a consultant, both with a long history of supporting the implementation of IB programs. Each school was visited three or four times during the school year and in a few instances faculties from all of the pilot schools in a district met. CPRE staff spent 17 days in Anne Arundel, 14 days in Nashville, and 17 days in Palm Beach.

None of the schools had assigned instructional coaches which was the original idea for on-site support. Budget cuts quickly eliminated that option and the IB coordinators were 
asked to assume that role but were given limited release time to do the work. The CPRE visits provided a less intense form of coaching. Site visits typically included classroom observations and feedback, after school peer coaching sessions, and cohort learning sessions. Most teachers accepted the classroom visits and feedback although several in Nashville did want to be observed. The schools all have block scheduling so the CPRE visitor would visit two teachers per block, covering eight teachers in a day. The observations would focus on a practice the teacher selected or on one or two of the high impact practices. After school, all the teachers met to discuss the Peer Coaching protocol or to look at school work together. CPRE staff also led walk-throughs with the district IB coordinators and school administrators and planning sessions with the district IB coordinator.

Although there were common areas of work across the eight schools and three districts, as the year progressed, the work became more contextual based on the needs of the teachers and the school.

Summer Institutes were also conducted in each district. These lasted two to three days, and had a common agenda. They focused on the elements of the MYP, how to observe classrooms, the high-impact practices, how to diagnose student needs, and how to engage students.

Teachers Responses to the On-Site Support. While the teacher survey included questions about teacher participation in various forms of professional development, there were not any survey questions directed explicitly at the on-site support provided by CPRE or IB. The reasoning was that these aspects of the project could be assessed through interviews conducted in the schools. In retrospect, this was a missed opportunity to assess the impact of the on-site support.

Of the interview respondents who participated in the on-site learning activities, 87 percent indicated that the support was helpful to very helpful.

"Bill Stroud has become our favorite person. He is always throwing ideas and questions out. He is practical and reasonable and has his finger on the pulse." DP Coordinator

"Bill will sit in classes and meet with you one-on-one. I find him the most helpful of anyone we've worked with."

MYP Language A Teacher

"It's like a buzz in my ear; I hear him [Bill] telling me to be reflective."

MYP Science Teacher

"Niki is helpful in a very concrete way. I can use what she works with us on in the classroom the next day."

MYP Math Teacher

However, teachers, coordinators and principals offered many suggestions for how the on-site support could be strengthened: more frequent visits; follow-up reports and 
emails; spending more time at a school each visit; spending more time in individual coaching; and spending more time with district coordinators and principals.

"The on-site work has been very helpful but it is hard to sustain momentum. We need more consistent support."

MYP Coordinator

"I would like a debriefing or a follow-up report if we can't meet before he leaves. Something to help me know what next steps I should expect to see."

Principal

There also were some comments about the apparent disconnect between the on-site support and the tools being developed by IB. Both teachers and administrators perceived a need for better coordination between the various elements of the project.

"There is clearly friction between Columbia and IB. We aren't getting the help we need which is how to help the target kids from anybody."

MYP Coordinator

"If you ask the teachers what they are most enthusiastic about [with the project] it is the on-site support but l'm not sure what we're learning and what is replicable about this work."

IB Staff Member

When teachers were asked to be specific about what the on-site support changed about their classroom practices they mentioned a number of things: assessment practices including the use of rubrics; close reading; unit planning; attending to the cognitive demand of lessons; being thoughtful about integrating areas of interaction into lessons; and using high-impact practices in a more intentional way.

"I feel like this on-site support is my one "safe" place in my work. Bill does not judge; he is very approach-able and listens carefully when I explain my problems. He gives me the encouragement to try new things."

MYP Language A Teacher

The respondents who did not find the on-site support helpful listed a variety of reasons: changes made from what was planned; the content of PD sessions was too vague and not useful in the classroom; sessions were held in rooms not conducive to learning; the sessions were not focused on the target students; and too few sessions had an impact on their practice.

"I admire the passion but the suggestions don't help me with the kids this project targets."

MYP Language A Teacher

"We need more help on concrete things like unit planning and less time on reflection."

MYP Math Teacher 
"What we found is that when she [Niki] comes it is like Level I training; we have already had that."

In Year 3, IB has contracted with another consultant to provide assistance with building the leadership infrastructure at the school level. This new activity increases the need to strengthen the coordination among the various streams of assistance to the schools.

\section{Communities of Practice}

On the CPRE survey, teachers were asked a number of questions about their interactions with colleagues in their schools. These items are indicators of the strength of the professional communities in each school. Because these items invite socially acceptable responses, they exaggerate the quantity and quality of professional interactions and collaboration, but they do provide relative measures of the strength of professional cultures across the schools. In Table 15, below, the teachers' responses are reported by school. 
Table 15

Indicators of Communities of Practice

Year 2

(Percent of Teachers by School Responding Agree or Strongly Agree

Or Sometimes and Often)

\begin{tabular}{|c|c|c|c|c|c|c|c|c|}
\hline \multirow[t]{2}{*}{ Indicators } & \multicolumn{3}{|c|}{ Anne Arundel County } & \multicolumn{2}{|c|}{ Nashville } & \multicolumn{3}{|c|}{ Palm Beach } \\
\hline & $\begin{array}{c}\text { Annapolis } \\
\text { N }=17\end{array}$ & $\begin{array}{l}\text { Meade } \\
N=7\end{array}$ & $\begin{array}{c}\text { Old } \\
\text { Mill } \\
\mathrm{N}=5\end{array}$ & $\begin{array}{l}\text { Hillsboro } \\
\mathrm{N}=19\end{array}$ & $\begin{array}{l}\text { Hunters } \\
\text { Lane } \\
\mathrm{N}=7\end{array}$ & $\begin{array}{l}\text { Atlantic } \\
\qquad N=7\end{array}$ & $\begin{array}{c}\text { Forest } \\
\text { Hill } \\
N=7\end{array}$ & $\begin{array}{c}\text { Pahokee } \\
\text { N }=5\end{array}$ \\
\hline $\begin{array}{l}\text { The MYP has fostered } \\
\text { greater collaboration } \\
\text { among teachers in my } \\
\text { school }\end{array}$ & 71 & 71 & 40 & 65 & 100 & 71 & 71 & 100 \\
\hline $\begin{array}{l}\text { The MYP has } \\
\text { contributed to a sense } \\
\text { of professional } \\
\text { community in my school }\end{array}$ & 76 & 86 & 80 & 60 & 71 & 86 & 86 & 67 \\
\hline $\begin{array}{l}\text { Met with other MYP } \\
\text { teachers in small study } \\
\text { groups monthly or more }\end{array}$ & 59 & 100 & 100 & 60 & 71 & 0 & 57 & 67 \\
\hline $\begin{array}{l}\text { I meet with other } \\
\text { teachers to analyze } \\
\text { student work }\end{array}$ & 41 & 57 & 100 & 45 & 57 & 0 & 43 & 33 \\
\hline $\begin{array}{l}\text { I meet with other } \\
\text { teachers to analyze } \\
\text { student performance } \\
\text { data }\end{array}$ & 41 & 86 & 20 & 50 & 71 & 29 & 29 & 67 \\
\hline $\begin{array}{l}\text { I meet with other } \\
\text { teachers to discuss } \\
\text { needs of individual } \\
\text { students }\end{array}$ & 58 & 100 & 20 & 70 & 100 & 14 & 43 & 67 \\
\hline $\begin{array}{l}\text { Faculty in my } \\
\text { department share } \\
\text { information about } \\
\text { effective curricula }\end{array}$ & 71 & 71 & 80 & 60 & 43 & 57 & 57 & 67 \\
\hline $\begin{array}{l}\text { I observe other teachers } \\
\text { teach a class }\end{array}$ & 24 & 14 & 20 & 50 & 71 & 14 & 29 & 0 \\
\hline $\begin{array}{l}\text { Other teachers observe } \\
\text { my teaching }\end{array}$ & 18 & 29 & 20 & 30 & 29 & 0 & 14 & 0 \\
\hline
\end{tabular}

Responses to the first two items show that the MYP has created a sense of shared experience and a positive attitude toward the professional community in all eight schools. But as the items become more concrete, asking about specific kinds of shared activity, considerable variation appears. Responses from four or five of the schools suggest that structures are in place for collaborative work and that at least half of the staff participate. However, teachers report collaboration to analyze student work or 
examine student performance data is unusual in most of the schools. The last two items address the issue of making practice public and sharing instructional experiences. Here rates of participation are relatively low in all of the schools.

Teachers were organized into cohort groups to work together on instructional strategies and practices to assist underrepresented students in the MYP. These "learning teams" or communities of practice, while overwhelmingly supported as "a good idea" by the teachers and support staff interviewed, were perceived to have had a mixed impact on practice. A number of reasons were given including: lack of time to do collaborative work; too busy to meet with colleagues; no organizing belief or premise; turnover in staff; and other school and district agendas competing with the MYP project agenda.

The most consistently voiced barrier to collaborative work was lack of time.

"We are supposed to have some dedicated time to meet once every other week but the district makes us use the time for their agenda. You can't expect teachers to do everything afterschool."

MYP Math Teacher

"Even when we pay teachers to stay for cohort meetings, some of them don't....or won't."

MYP Coordinator

A number of teachers and coordinators indicated that a more compelling structure would be to have MYP and DP teachers meet together. There appear to be divides between these two communities in many of the pilot schools as well as lack of consistency in expectations for students and inclusiveness of admission policies and procedures.

"MYP teachers are the red-headed stepchildren. Most of the DP teachers don't even consider us IB teachers."

MYP Math Teacher

"MYP to DP articulation is lacking. The kids are hurt by this."

Assistant Principal

Some teachers said that meeting with their content-area department teachers or planning with a colleague who taught the same courses was more productive.

"We have too many meetings that don't go anywhere. I am at a place in my life where I have no patience for non-productive meetings."

MYP Science Teacher

What was most striking was that teachers were meeting on a regular basis in only a few schools when the on-site technical assisters were not there. The sustainability of collaborative practices in some of the schools without an external stimulus is questionable. 
"There is a lot of pressure for us to log into the new IB website; we're going to pay teachers to do that rather than meet together as a cohort group. Otherwise they won't do it."

MYP Coordinator

To be clear, there were teachers who valued the collaborative meetings and felt that they were members of a community of practice. But they appeared to be in the minority.

"I have really smart colleagues and, as a new teacher, I appreciate their experience and insight. It is very, very helpful for me to be in learning sessions with them."

MYP Language A Teacher

There were several teachers who felt that the students, especially the underrepresented students in the MYP, needed to feel like they belonged to a community of learners. In interviews, teachers spoke compellingly and passionately about the lack of role models for these students and the courage it takes for students who previously were not seen by others as good students and did not view themselves as "learners" to enter into the MYP and continue to the DP.

"These students walk by DP rooms and there are no students that look like them and no teachers that look like them. Why would they want to be part of this program?

MYP Language B Teacher

"We say we don't want to be an elitist program but I'm not sure that is true. There are parents and students and teachers who like that IB is considered to be for 'the chosen few."'

MYP Math Teacher

The challenge of "enlarging the circle" will be further discussed in the next section.

\section{Student Success and Underrepresented Students}

Are the schools making adjustments in classroom practices and routines to encourage and support participation by students of color and students from poor families to participate in the MYP and IB? First, we examine some survey data bearing on this question and then we look at the interview data.

Teachers who responded to the survey tend to feel that classroom supports are adequate and responsive to the needs of poor and minority students. They also report using good instructional practices. There is some disagreement over this in the Palm Beach schools - especially at Atlantic HS. However, teachers reported a lack of organizational supports - engaging parents, team planning, and provision of special attention to these non-traditional IB students. The survey data also show some variation by school in teachers' perceptions of how much attention is given to preparing MYP students for the DP program and how much attention is given to preparing poor and minority students for the DP. 
Table 16

Recruitment and Student Support

Year 2

(Percent of Teachers by School Responding Agree or Strongly Agree)

\begin{tabular}{|c|c|c|c|c|c|c|c|c|}
\hline \multirow[t]{2}{*}{ Indicators } & \multicolumn{3}{|c|}{ Anne Arundel County } & \multicolumn{2}{|c|}{ Nashville } & \multicolumn{3}{|c|}{ Palm Beach } \\
\hline & $\begin{array}{l}\text { Annapolis } \\
\qquad N=17\end{array}$ & $\begin{array}{l}\text { Meade } \\
\mathrm{N}=7\end{array}$ & $\begin{array}{l}\text { Old } \\
\text { Mill } \\
\mathrm{N}=5\end{array}$ & $\begin{array}{l}\text { Hillsboro } \\
\qquad N=19\end{array}$ & $\begin{array}{l}\text { Hunters } \\
\text { Lane } \\
N=7\end{array}$ & $\begin{array}{c}\text { Atlantic } \\
\mathrm{N}=7\end{array}$ & $\begin{array}{c}\text { Forest } \\
\text { Hill } \\
\mathrm{N}=7\end{array}$ & $\begin{array}{c}\text { Pahokee } \\
\mathrm{N}=5\end{array}$ \\
\hline $\begin{array}{l}\text { We provide adequate } \\
\text { support to students to } \\
\text { succeed in the MYP }\end{array}$ & 76 & 86 & 80 & 60 & 86 & 43 & 71 & 50 \\
\hline $\begin{array}{l}\text { We actively recruit } \\
\text { students of color }\end{array}$ & 76 & 100 & 60 & 90 & 100 & 43 & 100 & 67 \\
\hline $\begin{array}{l}\text { We provide safety nets } \\
\text { for students in the MYP } \\
\text { program who need } \\
\text { additional support }\end{array}$ & 65 & 100 & 80 & 80 & 86 & 43 & 57 & 67 \\
\hline $\begin{array}{l}\text { We actively engage } \\
\text { parents in support of } \\
\text { MYP students }\end{array}$ & 65 & 100 & 80 & 50 & 29 & 43 & 43 & 50 \\
\hline $\begin{array}{l}\text { We actively prepare all } \\
\text { MYP students to be } \\
\text { successful in the DP }\end{array}$ & 71 & 86 & 100 & 40 & 86 & 71 & 71 & 50 \\
\hline $\begin{array}{l}\text { We adequately plan as } \\
\text { a MYP team to ensure } \\
\text { students have a } \\
\text { manageable workload }\end{array}$ & 18 & 71 & 40 & 50 & 86 & 14 & 29 & 50 \\
\hline $\begin{array}{l}\text { We employ a wide } \\
\text { variety of instructional } \\
\text { strategies }\end{array}$ & 94 & 86 & 100 & 90 & 100 & 71 & 71 & 83 \\
\hline $\begin{array}{l}\text { We adequately } \\
\text { differentiate in class }\end{array}$ & 82 & 86 & 80 & 60 & 86 & 57 & 86 & 50 \\
\hline $\begin{array}{l}\text { We use a variety of } \\
\text { formative assessment } \\
\text { strategies }\end{array}$ & 82 & 100 & 100 & 80 & 86 & 43 & 86 & 83 \\
\hline $\begin{array}{l}\text { We give special } \\
\text { attention to students of } \\
\text { color and poor students } \\
\text { to ensure they continue } \\
\text { into the DP }\end{array}$ & 59 & 71 & 20 & 70 & 86 & 43 & 43 & 83 \\
\hline $\begin{array}{l}\text { We review instructional } \\
\text { strategies to determine } \\
\text { those that are most } \\
\text { useful }\end{array}$ & 59 & 71 & 80 & 70 & 100 & 43 & 86 & 67 \\
\hline
\end{tabular}

The teachers, coordinators and principals continue to believe that students who have historically not been included in the MYP can be successful, especially with increased support. The Year 2 interview responses were less about beliefs and more about perceived barriers to making beliefs a reality. Teachers cited a number of conditions and cultural reasons that students were not entering, staying in, or meeting with success in both the MYP and the DP. The reasons cited included: not feeling included in the IB community; not wanting to do the work; not having an understanding of the 
benefits of the program; not wanting to be seen as a "geek"; not having friends in the program; and not having the support at home.

"Getting them to jump in the water when they think the water is too deep is the challenge. They tell us they don't want to do the work. They don't want to be seen as a "smart" kid, a "geek." They don't want to spend their weekends writing a 5,000 word paper."

Principal

"These are students of generational poverty. There is a low emphasis on education in their homes coupled with low literacy and not a lot of hope."

MYP Language A Teacher

"It's hard to have a global perspective because life at home is so difficult. Our kids truly have immediate problems of survival."

MYP Math Teacher

School and district staff cited supports that they had put in place to assist the underrepresented and struggling students. With few exceptions the supports were typical of what schools and districts would do for any struggling students such as tutoring, mentoring, Saturday school and counseling support.

"We do the usual: tutoring, counseling, finding the student a mentor. But it isn't enough. Not nearly."

MYP Language A Teacher

"We need to do a whole lot more with the families. We say they won't come up here but I don't think that's true. I think we say that because we don't want to mess with it; we're not sure what to say."

MYP Math Teacher

"We didn't do what we set out to do which was give them the support they need to be successful."

MYP Coordinator

Some more innovative actions included analyzing the students who were leaving the program and designing supports specific to them and creating a course that focused on writing, recognizing that this was an area that was often difficult for students, especially those without strong academic backgrounds.

"We looked at who was leaving after ninth grade and it was disproportionately African American females. We started a group for these girls in ninth grade with the hope of supporting them through the difficult times when typically they decide to leave the program."

DP Coordinator

As was the case in Year 1, all of the teachers who were interviewed were aware of their school's involvement in the Access project and overwhelmingly, teachers were interested in and supportive of the goals. There were teachers, as in Year 1, who 
indicated that they had asked to be part of the project because the focus on inclusion of all students in high-level coursework was a personal or professional belief. In Year 2, however, more of the teachers expressed concern about whether the targeted students would be successful and even fewer believed that these students would be encouraged to move into the DP.

"You have to understand that more than three-quarters of our students at this school are reading below grade level and half of the students, it is significantly below grade level. They need lots of support just to do grade-level work not to mention the rigorous, high-level work that the IB program requires. I'm just not sure that given our limited resources we will be successful with these students. We're trying, I can promise you that. But it is a struggle."

MYP Coordinator

"These students need faculty members and counselors to help them. They need focus and a reason to do the work. Our kids need hope."

Assistant Principal

"What do you do when they don't want to do the work? They don't want to be the kids in the school with a backpack when all the other kids don't take anything home at night."

MYP Language A Teacher

Other challenges to moving the targeted students into the DP were raised. As stated during Year 1 interviews, we continued to hear that the biggest obstacle to student success in the DP was the attitudes of the teachers teaching the DP courses. The lack of articulation between and among MYP and DP teachers makes this a challenge for the students. If a student meets with success in the MYP and is counseled to continue on to the DP, one might assume that this progression was seamless. From our data, this is an inaccurate assumption.

"I am not convinced that some of the DP teachers will provide additional supports so these students will stay in the program and be successful. In fact, I'm fairly sure they won't."

MYP Math Teacher

During the 2011-2012 school year, all but two of the pilot schools will be serving all ninth and tenth grade students in the MYP. While there are some advantages to this schoolwide approach, the primary disadvantage will be that this will be "regular" curriculum and there may be less pressure to identify and prepare selected students for the DP program. No schools have indicated that they plan to go "whole-school" IB.

"We are a choice DP program; we always have been and always will be."

DP Coordinator

As was the case in Year 1, many of the interviewed teachers and coordinators believed that the project increased the feeling of hope and equity in their schools. There were administrators who said it was their intention that IB components be infused in all classes and that the kind of instruction they were observing in the MYP and the DP was 
the kind of practices they wanted all teachers to employ because all students deserved rigorous, high-quality instruction.

"We have to insist that we throw away the old lesson plans that don't require students to think and give all students the kind of instruction that will prepare them for college."

Principal

\section{Enacting the Theory of Change}

The IB has laid out a logic model that delineates its theory of change (see the diagram on page 5). We were interested in how closely the school and district staff's beliefs mirrored those held by the IB staff.

The IB's premises for student success are as follows:

- Teacher collaboration around the written, taught and assessed curriculum will lead to improved instruction for all students;

- Strategies and resources provided by the project will be beneficial to all, but are essential to fill in gaps for targeted students;

- As a result of the new tools, materials, and technical assistance, classroom practice will improve; and as a result of improved classroom practice, more students will be engaged in learning and prepared for the Diploma Programme;

- Teachers views about which students can succeed in DP may change as they experience success teaching a broader range of students; and

- Work around school policy and practice will remove barriers to expanded participation in the DP.

Analysis of interview responses suggests differing degrees of agreement on the part of school and district project participants with the IB Access Project Theory of Change. We will explore this premise by premise.

Teacher collaboration around the written, taught and assessed curriculum will lead to improved instruction for all students. While both the survey and the interview data show teachers support collaboration and that it occurs to some degree in all of the schools, the effectiveness of the structures for collaboration varies across the schools, the time available is not sufficient, and therefore the amount and nature of the collaboration varies.

There also appears to be some dissonance around what kinds of development work teachers are expected to do, the degree to which they are expected to use IBdeveloped units and assessments, and what the expectations are for and what constitutes collaborative work. It is clear that the support mechanisms to date have focused largely on the on-site technical assistance but teachers still seem overwhelmed by the sheer immensity of the task of learning the MYP and figuring out how to incorporate its components into their day-to-day teaching. Much of this could be due to the large number of new or nearly new teachers who are participating in the project and the high teacher turnover in some schools. 
"When I first started going to Bill's meetings I had no idea what he was talking about. I had no MYP training and I was just trying to make sense of things like the Learner Profile and Areas of Inter-action. And I was teaching ninth graders who were not that easy to teach."

MYP Math Teacher

"It took me awhile to understand how the unit planner was supposed to be set up. I guess it will help me organize my teaching but right now connecting with the kids is my biggest challenge and this is no help."

MYP Language A Teacher

\begin{abstract}
Strategies and resources provided by the project will be beneficial to all, but are essential to fill in gaps for targeted students. The interview respondents agreed with this tenet; however, there has been considerable frustration about what many felt was lack of understanding by the IB of the day-to-day challenges of teaching students with serious learning gaps. Reading difficulties were cited over and over again as a major challenge that, at times, felt insurmountable. At the time of the interviews, the new resources were still sparse and teachers felt frustrated with the lack of promised tools to assist in their planning for and delivering instruction, especially to the students targeted by the project.
\end{abstract}

"You have to understand there are lots of reasons we struggle with teaching these students; resources are only one of the challenges."

MYP Coordinator

"To be honest, I have not seen anything that IB has developed that can really help me with these targeted students."

MYP Science Teacher

More students will be engaged in learning and prepared for the Diploma

Programme. Student engagement is an area that teachers, coordinators and principals cite as critical to student success and retention in the MYP program. Obviously, if students drop out of the MYP, or do poorly in class, they will, in all likelihood, be ineligible for the DP. It remains unclear how many underrepresented students will advance to the DP, if they will be retained in the program, and ultimately achieve success.

"Our problem is not recruiting students to the MYP and the DP; it is retaining them. The attrition rate is higher than we would like and is most often the students targeted in this project."

DP Coordinator

Teachers views of which students can succeed in DP may change as they experience success teaching a broader range of students. What is clear from teacher comments is that there currently is a tenuous connection between the MYP and the DP in most of the pilot schools. The teachers of the MYP, for the most part, believe that a broader range of students can be successful in the DP, but there is a widely held belief that many of the DP teachers do not share this view. However, we do not have any evidence to confirm this belief. In Year 3, we expect to interview some of the 
students who were historically underrepresented in IB and who participated in the MYP in ninth and tenth grades and test this assumption.

"Until we do a better job at coordinating with the DP teachers our students are set up for failure if they elect to stay in IB. That is not right."

MYP Coordinator

\section{Work around school policy and practice will remove barriers to expanded} participation in the DP. In a number of schools, prerequisites for entry into the MYP and the DP have been removed and a new attitude of opening the program to any student who wants to try it is taking hold. In confidential interviews a number of teachers, however, challenged this practice as creating expectations for teachers that are unrealistic. Other teachers have suggested the policies and practices that are standing in the way of student success.

"I would like every student in the school to have the opportunity to be in rigorous coursework but that doesn't mean they should be in the MYP; there are too many requirements like CASS that if you don't have students that want to do the work, the teachers end up chasing kids down and extending deadlines and doing things that aren't fair to the students who follow the rules and do the work. A teacher can't change the attitude of a student who for years and years has refused to the work."

MYP Science Teacher

"It's the kids who take Algebra I as ninth graders that drop out. We need to support these students differently."

MYP Math Teacher

\section{District and School Theory of Change Components}

Project participants suggested that other factors contributed to student success in IB. Among these were: leadership knowledge of the IB and support for its implementation; the explicit understanding of what each student needs and the capacity to provide it; exposing students to life beyond high school; and engaging families at a very deep and personal level in the success of their child.

"If your principal isn't behind you and helping you with the parents and the resources, it is impossible to really make a go of IB with students who have so many needs."

MYP Math Teacher

"We have an AP assigned to us [the MYP] but he doesn't attend our meetings or show much interest in what we are doing. It is a problem. I don't have any leverage to 'make' teachers do anything, even come to the cohort meetings."

MYP Coordinator

"This year we started looking at a group of students and bringing information about their progress and copies of their work in their courses to meetings and it has really helped us realize that we have to know each student and provide individual support based on what is needed." 
"We should be taking these kids to college fairs and getting outside speakers in and doing a lot more to connect them to life beyond high school. They have no plans and it makes the work seem too hard to them."

MYP Coordinator

"We have a dedicated counselor who works with IB but she shouldn't be the only one communicating with parents. We have teachers who don't want to involve the parents in their kid's education."

MYP Language B Teacher

\section{Year Two Findings}

We have extracted some of the more salient findings from our data in two areas: promising indicators and challenges.

\section{Promising Indicators}

- Teachers overwhelming believe that the MYP is a good instructional program that provides rigorous, relevant learning opportunities for all students.

- The vast majority of project participants believe that underrepresented students can be successful in the MYP, especially with appropriate supports.

- With some exceptions, teachers report that they feel prepared and, to a lesser extent, use many of the high-impact practices in their day-to-day work with students.

- School and district coordinators, almost universally, are informed, interested and passionate about moving the agenda of underrepresented students forward.

- By the spring of Year 2, all pilot schools had a space and place for cohort teachers to collaborate and learn.

- Teachers indicate support for collaboration and work as a cohort and see benefits in planning and creating instructional materials and assessments with colleagues.

- Teachers report that they use the MYP-component of 'international-mindedness' in their day-to-day work with students.

- The majority of teachers value and welcome the technical assistance provided by the project.

- Most teachers indicate a willingness to continue to use the IB-developed website and resources and seem optimistic about the benefits of mentoring and on-site collaboration opportunities. 
- Teachers have been open to classroom visitations and feedback, and overwhelmingly expressed positive responses to on-line professional learning

\section{Challenges}

- Some teachers and administrators do not believe in the goals of this project, most notably at Atlantic and Forest Hill HS in Palm Beach and Old Mill HS in Anne Arundel County.

- In many of the pilot schools finding time for teacher collaboration has been difficult, limiting the face-to-face engagement of cohort members around the Access Project goals; consequently, sharing experiences and strategies and improving practice is difficult given these conditions.

- Although many teachers report feeling prepared to use high-impact instructional strategies and the instructional and assessment components of the MYP, and significant numbers report using the practices, technical assisters, coordinators and school administrators report that use of these teaching practices is limited.

- The literacy skills of many of the students in the targeted populations are a major challenge for MYP, and ultimately DP teachers. They need help in thinking about to address this need.

- Project cohorts are ever-changing; teachers who are new to teaching or have not had MYP training are often included in this work and some seem overwhelmed by it. It is difficult to get traction or to assess progress with the constant teacher churn. When more schools go school-wide with MYP next year, additional teachers will be added to the project and more training will be required. The constant turnover in some of the pilot schools makes determining the impact of the tools and supports difficult to ascertain.

- There remains a huge divide between the MYP and the DP teachers, students and programs. This must be mediated if the MYP students, especially the targeted students in this project, are to experience success in the DP.

- The lack of evident infrastructure supports in schools and districts leaves the sustainability of this work in question.

- The IB-developed tools and resources have not been integrated into the work of enough teachers to use feedback about the utility of these supports with any confidence.

- Some teachers and other participants do not see how the various supports provided by the project match the grant's focus on underrepresented students; there remains frustration about how to increase the retention and success of underrepresented students in the MYP and how to move them successfully into the DP. 
Not all of the schools have identified students this grant targets nor developed plans for supporting them; this especially apparent when trying to understand the percentages of MYP and DP students in poverty.

\section{Year Three Research Priorities}

There remain compelling, but unanswered questions about how to fully integrate historically underrepresented students into the MYP and DP and what teachers and other school-based and district-based educators can do to increase the likelihood of their success.

The discussions stimulated in the schools by the Project around serving underrepresented students have been insightful and have begun to change attitudes. Most participants report that they believe this is the primary focus of the project and the reason they wanted to be part of the work. Some teachers and school staff indicate some frustration with what they see as a lack of attention to specific strategies for moving this agenda forward. They indicate that the philosophy that "the rising tide will lift all boats" is not working; if it was working, they feel that underrepresented students would be doing much better and moving into DP at a higher rate. We will explore this further in Year 3 when we will interview underrepresented students who continue on to the DP and some that do not.

The MYP-DP progression is another area of study, for all students, but especially the underrepresented students. There are a host of reasons why MYP students don't continue to the DP. However; the underrepresented students, by most accounts, are the least likely to continue. While the practice of full-school MYP has a lot of merit, the fact is that the schools in our study that are implementing this practice are not implementing a similar practice of DP for all students. This speaks loudly to the differences between expectations for the students in the MYP and the students in the DP. For two years, some MYP teachers have reported that they are not considered IB teachers and that DP teachers call MYP "IB Lite." The lack of articulation between and among MYP teachers and DP teachers remains a tension, and an obstacle, to the goals of the Access Project. We will explore this apparent divide in Year 3 as some of the students in this project begin work in the DP.

Building capacity of school and district educators to continue the work of this project is part of the strategy for sustainability. We will explore the degree to which participants believe that they are able - and willing - to continue this work without grant money and the additional resources provided through this project.

There is still concern that the reported level of implementation of instructional strategies and assessments may not mirror the actual practices in classrooms. Technical assisters and administrators indicate that they are not observing MYP components in play and high-impact strategies in practice with any regularity. The turn-over of teachers and, to some extent, other key players have hindered the progress we would hope to see in any project that has the development and continuous improvement of professionals as a goal. It is unclear whether district or school coordinators will "step up" and lead the work 
in the absence of the technical assisters. In Year 3, we inquire about sustainability in the interviews and in the survey and examine exactly what steps coordinators, school leaders, and district officials are taking to sustain the work.

The findings suggest further research in areas of beliefs and expectations and coordination and communication between and among MYP and DP practitioners. Schools are very busy places and if collaboration is not designed into the work and valued by administrators, it is our experience that it won't happen. This will be particularly important as we observe for mechanisms for support of the underrepresented students transitioning from the MYP to the DP.

In Year 3 we will look closely at the sustainability plans and practices that will indicate the extent to which this work is "owned" by the pilot schools and districts. We will be interested in determining what structures and procedures are in place to support the students this project targeted, both at the school and district levels. We will look at the articulation practices between and among the MYP and the DP teachers and coordinators and the practices of the district coordinators that support a seamless transition between the two levels of IB.

\section{Research Methodology}

- Analysis of current participation and performance patterns (Document and web review and interviews of key players)

- Perceptions of teachers and key players (Teacher Survey)

- Analysis of Resources and Support (Interviews of key players, data from website use and workshop and mentoring participation)

- Analysis of Collaborative Learning (Observation of on-site professional development)

- Perceptions of Targeted Students (Interviews with former targeted MYP students who are in the DP and are not in the DP)

\section{Research Challenges}

The multi-site and multi-faceted nature of the project poses significant challenges to the evaluation team. One annual visit to each school site of short duration does not permit direct observation of classrooms and therefore we are forced to rely on self-reports through interviews and surveys to assess the use of the opportunities and tools being provided and the degree of use of new strategies in the classroom. Since surveys notoriously inflate the use of desired practices, we can assume that actual use is less than the reported use. Nonetheless, the surveys do reveal patterns of the changes in use over time and the relative amount of use across the eight sites. 
Moreover, the number of survey responses from each school is relatively small and one or two individuals can alter the pattern; and, the amount of turnover in some sites compounds the problem of identifying trends in survey responses.

In addition, we chose to administer the surveys during the Summer Institutes in order to reduce the burden of administration and to achieve acceptable response rates. This means we did not receive responses from teachers who for whatever reasons did not to attend the workshops. This may have further biased the survey results.

In the coming year, we will try to improve the survey by dropping some items that show little change or invite socially acceptable responses and adding more items targeted to specific aspects of the project such as on-site assistance. We also will explore ways of reaching teachers who do not attend the Summer Institutes.

In addition, we will examine the content of interviews conducted with individuals who have been part of the project from the first year through the coming year to see if we can identify trends in beliefs, attitudes, and practices.

\section{Timeline of Activities}

November-December 2011

January-February 2012

March 2012

March 2012

May 2012

June 2012

June 2012

August 31, 2012
Development of interview protocols

Web and document reviews for updates/ changes

On-site collection of data

Development of survey instrument

Mid-year update

Data analysis

Survey administration and observation at Summer

Institutes

District and school coordinators updates

Final Report development

Final Report submitted to IB

\section{Deliverables}

- Mid-year update on evaluation activities and feedback on resources

- Final report that includes evaluation of new resources; suggestions for future resource development; analysis of changes in teacher practice; analysis of enrollment and performance patterns in the MYP and the DP; and recommendations for additional support to increase student participation and improve student performance 


\section{References}

Corcoran, T.B. and Silander M. (2008). Instruction in high schools: What do we know? In C. Rouse and J. Kemple (Eds.), America's high schools. Princeton, NJ: The Future of Children.

Corcoran, T. B., Silander, M., and Stroud, W. (in preparation). High-impact classroom practices: What every teacher should know and do. New York, NY: CPRE.

Hattie, J. A. C. (2009). Visible learning: A synthesis of over 800 meta-analyses related to achievement. Oxford: Routledge. 


\section{Appendix A: Participation}

School: Annapolis High School

Student Participation (2010-2011)

\begin{tabular}{|l|c|c|c|c|c|c|c|c|}
\hline \multicolumn{1}{|c|}{ MYP } & ELL & \multicolumn{2}{c|}{ Gender } & \multicolumn{4}{c|}{ Ethnicity } & FRL \\
\hline & & Male & Female & Asian & Black & Hispanic & White & \\
\hline 9th & 4 & 56 & 66 & 6 & 11 & 7 & 98 & - \\
\hline 10th & 4 & 46 & 49 & 10 & 6 & 4 & 75 & - \\
\hline \hline TOTAL & 8 & 102 & 115 & 16 & 17 & 11 & 173 & 27 \\
\hline
\end{tabular}

\begin{tabular}{|c|c|c|c|c|c|c|c|c|}
\hline \multirow[t]{2}{*}{ DP } & ELL & \multicolumn{2}{|c|}{ Gender } & \multicolumn{4}{|c|}{ Ethnicity } & \multirow{2}{*}{ FRL } \\
\hline & & Male & Female & Asian & Black & Hispanic & White & \\
\hline 11th & 1 & 30 & 41 & 3 & 8 & 2 & 58 & - \\
\hline 12th & 2 & 32 & 36 & 6 & 13 & 4 & 45 & - \\
\hline Certificate & NA & & & & & & & \\
\hline TOTAL & 3 & 62 & 77 & 9 & 21 & 6 & 113 & 13 \\
\hline
\end{tabular}

Projected Student Participation (2011-2012)

\begin{tabular}{|c|c|c|c|c|c|c|c|c|}
\hline \multirow{2}{*}{ MYP } & ELL & \multicolumn{2}{|c|}{ Gender } & \multicolumn{4}{|c|}{ Ethnicity } & FRL \\
\hline & & Male & Female & Asian & Black & Hispanic & White & \\
\hline 9th & 0 & 37 & 50 & 4 & 6 & 13 & 63 & 9 \\
\hline 10th & 0 & 57 & 60 & 9 & 6 & 7 & 93 & 16 \\
\hline TOTAL & 0 & 94 & 110 & 13 & 12 & 20 & 156 & 25 \\
\hline
\end{tabular}

\begin{tabular}{|c|c|c|c|c|c|c|c|c|}
\hline \multirow[t]{2}{*}{ DP } & \multirow[t]{2}{*}{ ELL } & \multicolumn{2}{|c|}{ Gender } & \multicolumn{4}{|c|}{ Ethnicity } & \multirow[t]{2}{*}{ FRL } \\
\hline & & Male & Female & Asian & Black & Hispanic & White & \\
\hline 11th & 0 & 29 & 45 & 9 & 5 & 5 & 55 & 9 \\
\hline 12th & 0 & 25 & 39 & 3 & 6 & 2 & 53 & 3 \\
\hline Certificate & NA & & & & & & & \\
\hline TOTAL & 0 & 54 & 85 & 12 & 12 & 7 & 108 & 13 \\
\hline
\end{tabular}

Diploma Activity

\begin{tabular}{|c|c|c|c|c|c|c|c|c|}
\hline \multirow[t]{2}{*}{ DIPLOMAS } & \multirow[t]{2}{*}{ ELL } & \multicolumn{2}{|c|}{ Gender } & \multicolumn{4}{|c|}{ Ethnicity } & \multirow[t]{2}{*}{ FRL } \\
\hline & & Male & Female & Asian & Black & Hispanic & White & \\
\hline $\begin{array}{l}\text { \# of IB diploma } \\
\text { candidates }\end{array}$ & 0 & 30 & 35 & 6 & 12 & 4 & 43 & - \\
\hline \# of IB diplomas & 0 & 11 & 13 & 2 & 1 & 2 & 19 & - \\
\hline $\begin{array}{l}\text { \# of IB certificate } \\
\text { students }\end{array}$ & NA & & & & & & & \\
\hline$\#$ of IB certificates & NA & & & & & & & \\
\hline TOTAL & 0 & 41 & 48 & 8 & 13 & 6 & 62 & - \\
\hline
\end{tabular}


School: Meade High School

Student Participation (2010-2011)

\begin{tabular}{|c|c|c|c|c|c|c|c|c|}
\hline \multirow[t]{2}{*}{ MYP } & \multirow[t]{2}{*}{ ELL } & \multicolumn{2}{|c|}{ Gender } & \multicolumn{4}{|c|}{ Ethnicity } & \multirow[t]{2}{*}{ FRL } \\
\hline & & Male & Female & Asian & Black & Hispanic & White & \\
\hline 9th & 0 & 39 & 82 & 15 & 58 & 6 & 41 & - \\
\hline 10th & 0 & 34 & 51 & 16 & 30 & 8 & 31 & - \\
\hline TOTAL & 0 & 73 & 133 & 31 & 88 & 14 & 72 & - \\
\hline
\end{tabular}

\begin{tabular}{|l|c|c|c|c|c|c|c|c|}
\hline DP & ELL & \multicolumn{2}{|c|}{ Gender } & \multicolumn{4}{c|}{ Ethnicity } & FRL \\
\hline & & Male & Female & Asian & Black & Hispanic & White & \\
\hline 11 th & 0 & 24 & 40 & 13 & 18 & 4 & 29 & - \\
\hline 12 th & 0 & 17 & 20 & 2 & 21 & 1 & 13 & - \\
\hline Certificate & NA & & 2 & 2 & & & & \\
\hline TOTAL & 0 & 41 & 62 & 17 & 39 & 5 & 42 & \\
\hline
\end{tabular}

Projected Student Participation (2011-2012)

\begin{tabular}{|c|c|c|c|c|c|c|c|c|}
\hline MYP & ELL & & ider & & & city & & FRL \\
\hline & & Male & Female & Asian & Black & Hispanic & White & \\
\hline 9th & 0 & 25 & 54 & 11 & 38 & 5 & 25 & - \\
\hline 10th & 0 & 30 & 73 & 14 & 49 & 3 & 37 & - \\
\hline TOTAL & 0 & 55 & 127 & 25 & 87 & 8 & 62 & - \\
\hline
\end{tabular}

\begin{tabular}{|l|c|c|c|c|c|c|c|c|}
\hline DP & ELL & \multicolumn{2}{|c|}{ Gender } & \multicolumn{4}{c|}{ Ethnicity } & FRL \\
\hline & & Male & Female & Asian & Black & Hispanic & White & \\
\hline 11th & 0 & 26 & 40 & 15 & 20 & 7 & 24 & - \\
\hline 12th & 0 & 23 & 38 & 12 & 18 & 4 & 27 & - \\
\hline Certificate & NA & & & & & & & \\
\hline TOTAL & 0 & 49 & 78 & 27 & 38 & 11 & 51 & - \\
\hline
\end{tabular}

Diploma Activity (2010-2011)

\begin{tabular}{|c|c|c|c|c|c|c|c|c|}
\hline \multirow[t]{2}{*}{ DIPLOMAS } & \multirow[t]{2}{*}{ ELL } & \multicolumn{2}{|c|}{ Gender } & \multicolumn{4}{|c|}{ Ethnicity } & \multirow[t]{2}{*}{ FRL } \\
\hline & & Male & Female & Asian & Black & Hispanic & White & \\
\hline $\begin{array}{l}\text { \# of IB diploma } \\
\text { candidates }\end{array}$ & 0 & 24 & 39 & 13 & 18 & 4 & 28 & - \\
\hline \# of IB diplomas & 0 & 7 & 3 & 0 & 1 & 1 & 8 & - \\
\hline $\begin{array}{l}\text { \# of IB certificates } \\
\text { students }\end{array}$ & NA & & & & & & & \\
\hline \# of IB certificates & NA & & & & & & & \\
\hline TOTAL & 0 & 94 & 42 & 13 & 19 & 5 & 36 & - \\
\hline
\end{tabular}




\section{School: Old Mill High School}

Student Participation (2010-2011)

\begin{tabular}{|c|c|c|c|c|c|c|c|c|}
\hline MYP & ELL & & ider & & & city & & FRL \\
\hline & & Male & Female & Asian & Black & Hispanic & White & \\
\hline 9th & 0 & 36 & 59 & 13 & 14 & 4 & 63 & 16 \\
\hline 10th & 0 & 38 & 44 & 16 & 19 & 1 & 46 & 8 \\
\hline$\overline{\text { TOTAL }}$ & 0 & 74 & 103 & 29 & 33 & 5 & 109 & 24 \\
\hline
\end{tabular}

\begin{tabular}{|l|c|c|c|c|c|c|c|c|}
\hline DP & ELL & \multicolumn{2}{|c|}{ Gender } & \multicolumn{4}{c|}{ Ethnicity } & FRL \\
\hline & & Male & Female & Asian & Black & Hispanic & White & \\
\hline 11 th & 0 & 23 & 40 & 4 & 13 & 2 & 43 & 4 \\
\hline 12 th & 0 & 38 & 60 & 11 & 26 & 2 & 57 & 4 \\
\hline Certificate & NA & & & & & & & \\
\hline TOTAL & 0 & 61 & 100 & 15 & 39 & 4 & 100 & 8 \\
\hline
\end{tabular}

Projected Student Participation (2011-2012)

\begin{tabular}{|c|c|c|c|c|c|c|c|c|}
\hline \multirow[t]{2}{*}{ MYP } & \multirow[t]{2}{*}{ ELL } & \multicolumn{2}{|c|}{ Gender } & \multicolumn{4}{|c|}{ Ethnicity } & \multirow[t]{2}{*}{ FRL } \\
\hline & & Male & Female & Asian & Black & Hispanic & White & \\
\hline 9th & 0 & 24 & 57 & 15 & 18 & 6 & 42 & 200 \\
\hline 10th & 0 & 34 & 51 & 11 & 13 & 4 & 56 & 14 \\
\hline TOTAL & 0 & 58 & 108 & 26 & 31 & 10 & 98 & 214 \\
\hline
\end{tabular}

\begin{tabular}{|l|c|c|c|c|c|c|c|c|}
\hline DP & ELL & \multicolumn{2}{|c|}{ Gender } & \multicolumn{4}{c|}{ Ethnicity } & FRL \\
\hline & & Male & Female & Asian & Black & Hispanic & White & \\
\hline 11th & 0 & 33 & 39 & 14 & 17 & 1 & 40 & 8 \\
\hline 12th & 0 & 21 & 36 & 3 & 13 & 2 & 38 & 3 \\
\hline Certificate & NA & & & & & & & \\
\hline TOTAL & 0 & 54 & 75 & 17 & 30 & 3 & 78 & 11 \\
\hline
\end{tabular}

Diploma Activity (2010-2011)

\begin{tabular}{|l|c|c|c|c|c|c|c|c|}
\hline DIPLOMAS & ELL & \multicolumn{2}{|c|}{ Gender } & \multicolumn{4}{|c|}{ Ethnicity } & FRL \\
\hline & & Male & Female & Asian & Black & Hispanic & White & \\
\hline $\begin{array}{l}\text { \# of IB diploma } \\
\text { candidates }\end{array}$ & 0 & 37 & 58 & 11 & 27 & 2 & 59 & 12 \\
\hline \# of IB diplomas & 0 & 9 & 24 & 5 & 6 & 2 & 21 & 2 \\
\hline $\begin{array}{l}\text { \# of IB certificate } \\
\text { students }\end{array}$ & NA & & & & & & & \\
\hline \# of IB certificates & NA & & & & & & & \\
\hline \hline TOTAL & 0 & 46 & 82 & 16 & 33 & 4 & 80 & 14 \\
\hline
\end{tabular}




\section{School: Hillsboro High School}

Student Participation (2010-2011)

\begin{tabular}{|l|c|c|c|c|c|c|c|c|}
\hline \multirow{2}{*}{ MYP } & ELL & \multicolumn{2}{|c|}{ Gender } & \multicolumn{4}{c|}{ Ethnicity } & FRL \\
\hline & & Male & Female & Asian & Black & Hispanic & White & \\
\hline 9th & 1 & 149 & 138 & 6 & 148 & 8 & 125 & 129 \\
\hline 10th & 4 & 127 & 151 & 1 & 143 & 8 & 126 & 112 \\
\hline TOTAL & 5 & 276 & 289 & 7 & 291 & 16 & 251 & 241 \\
\hline
\end{tabular}

\begin{tabular}{|l|c|c|c|c|c|c|c|c|}
\hline DP & ELL & \multicolumn{2}{|c|}{ Gender } & \multicolumn{4}{c|}{ Ethnicity } & FRL \\
\hline & & Male & Female & Asian & Black & Hispanic & White & \\
\hline 11th & 0 & 20 & 11 & 1 & 10 & 3 & 17 & 7 \\
\hline 12th & 0 & 20 & 17 & 2 & 4 & 1 & 30 & 0 \\
\hline Certificate & 0 & 7 & 14 & 2 & 2 & 3 & 14 & 4 \\
\hline \hline TOTAL & 0 & 47 & 42 & 5 & 16 & 7 & 61 & 11 \\
\hline
\end{tabular}

Projected Student Participation (2011-2012)

\begin{tabular}{|l|c|c|c|c|c|c|c|c|}
\hline MYP & ELL & \multicolumn{2}{|c|}{ Gender } & \multicolumn{4}{c|}{ Ethnicity } & FRL \\
\hline & & Male & Female & Asian & Black & Hispanic & White & \\
\hline 9th & 4 & 128 & 132 & 14 & 117 & 7 & 122 & 80 \\
\hline 10th & 1 & 149 & 138 & 6 & 148 & 8 & 125 & 129 \\
\hline \hline TOTAL & 5 & 277 & 270 & 20 & 265 & 15 & 247 & 209 \\
\hline
\end{tabular}

\begin{tabular}{|l|c|c|c|c|c|c|c|c|}
\hline DP & ELL & \multicolumn{2}{|c|}{ Gender } & \multicolumn{4}{c|}{ Ethnicity } & FRL \\
\hline & & Male & Female & Asian & Black & Hispanic & White & \\
\hline 11th & 1 & 27 & 50 & 2 & 22 & 3 & 50 & 13 \\
\hline 12th & 0 & 20 & 11 & 1 & 10 & 3 & 17 & 7 \\
\hline Certificate & 4 & 31 & 30 & 4 & 22 & 5 & 30 & 15 \\
\hline TOTAL & 5 & 78 & 91 & 7 & 54 & 11 & 97 & 35 \\
\hline
\end{tabular}

Diploma Activity (2010-2011)

\begin{tabular}{|l|c|c|c|c|c|c|c|c|}
\hline DIPLOMAS & ELL & \multicolumn{2}{|c|}{ Gender } & \multicolumn{4}{c|}{ Ethnicity } & FRL \\
\hline & & Male & Female & Asian & Black & Hispanic & White & \\
\hline $\begin{array}{l}\text { \# of IB diploma } \\
\text { candidates }\end{array}$ & 0 & 19 & 20 & 5 & 4 & 1 & 29 & 7 \\
\hline \# of IB diplomas & 0 & 9 & 11 & 2 & 1 & 0 & 17 & 4 \\
\hline $\begin{array}{l}\text { \# of IB certificate } \\
\text { students }\end{array}$ & 1 & 8 & 14 & 3 & 2 & 3 & 14 & 3 \\
\hline \# of IB certificates & 0 & 58 & 44 & 8 & 15 & 9 & 70 & 0 \\
\hline \hline TOTAL & 1 & 27 & 34 & 8 & 6 & 4 & 43 & 7 \\
\hline
\end{tabular}




\section{School: Hunters Lane}

Student Participation (2010-2011)

\begin{tabular}{|c|c|c|c|c|c|c|c|c|}
\hline \multirow{2}{*}{ MYP } & \multirow{2}{*}{ ELL } & \multicolumn{2}{|c|}{ Gender } & \multicolumn{4}{|c|}{ Ethnicity } & \multirow{2}{*}{ FRL } \\
\hline & & Male & Female & Asian & Black & Hispanic & White & \\
\hline 9th & 0 & 30 & 36 & 2 & 27 & 18 & 19 & 50 \\
\hline 10th & 0 & 20 & 28 & 1 & 25 & 4 & 18 & 35 \\
\hline$\overline{\text { TOTAL }}$ & 0 & 50 & 64 & 3 & 52 & 22 & 37 & 85 \\
\hline
\end{tabular}

\begin{tabular}{|c|c|c|c|c|c|c|c|c|}
\hline DP & ELL & & der & & Eth & city & & FRL \\
\hline & & Male & Female & Asian & Black & Hispanic & White & \\
\hline 11th & 0 & 10 & 15 & 0 & 17 & 4 & 4 & 16 \\
\hline 12th & 0 & 7 & 12 & 3 & 10 & 2 & 4 & 13 \\
\hline Certificate & 0 & 2 & 3 & 0 & 2 & 2 & 1 & 0 \\
\hline TOTAL & 0 & 19 & 30 & 3 & 29 & 8 & 9 & 39 \\
\hline
\end{tabular}

Projected Student Participation (2011-2012)

\begin{tabular}{|l|c|c|c|c|c|c|c|c|}
\hline MYP & ELL & \multicolumn{2}{|c|}{ Gender } & \multicolumn{4}{c|}{ Ethnicity } & FRL \\
\hline & & Male & Female & Asian & Black & Hispanic & White & \\
\hline 9th & 0 & 17 & 28 & 0 & 28 & 5 & 11 & * \\
\hline 10th & 0 & 25 & 30 & 4 & 25 & 19 & 14 & $50^{*}$ \\
\hline TOTAL & 0 & 42 & 58 & 4 & 53 & 24 & 25 & $50^{*}$ \\
\hline
\end{tabular}

\begin{tabular}{|c|c|c|c|c|c|c|c|c|}
\hline \multirow[t]{2}{*}{ DP } & \multirow[t]{2}{*}{ ELL } & \multicolumn{2}{|c|}{ Gender } & \multicolumn{4}{|c|}{ Ethnicity } & \multirow[t]{2}{*}{ FRL } \\
\hline & & Male & Female & Asian & Black & Hispanic & White & \\
\hline 11th & 0 & 12 & 20 & 1 & 11 & 3 & 17 & * \\
\hline 12th & 0 & 10 & 15 & 0 & 17 & 4 & 4 & $16^{*}$ \\
\hline Certificate & 0 & 4 & 4 & 0 & 6 & 1 & 1 & * \\
\hline TOTAL & 0 & 26 & 39 & 1 & 34 & 8 & 22 & $16^{*}$ \\
\hline
\end{tabular}

Diploma Activity (2010-2011)

\begin{tabular}{|l|c|c|c|c|c|c|c|c|}
\hline DIPLOMAS & ELL & \multicolumn{2}{|c|}{ Gender } & \multicolumn{4}{c|}{ Ethnicity } & FRL \\
\hline & & Male & Female & Asian & Black & Hispanic & White & \\
\hline $\begin{array}{l}\text { \# of IB diploma } \\
\text { candidates }\end{array}$ & 0 & 6 & 12 & 3 & 10 & 1 & 4 & 13 \\
\hline \# IB diplomas & 0 & 0 & 1 & 0 & 0 & 1 & 0 & 1 \\
\hline $\begin{array}{l}\text { \# of IB certificate } \\
\text { students }\end{array}$ & 0 & 2 & 0 & 0 & 0 & 1 & 1 & 2 \\
\hline \# of IB certificates & 0 & 39 & 72 & 18 & 60 & 7 & 26 & - \\
\hline \hline TOTAL & 0 & 47 & 85 & 21 & 70 & 10 & 31 & 16 \\
\hline
\end{tabular}

*Number for program/not grade level 
School: Atlantic Community High School

Student Participation (2010-2011)

\begin{tabular}{|l|c|c|c|c|c|c|c|c|}
\hline MYP & ELL & \multicolumn{2}{|c|}{ Gender } & \multicolumn{4}{c|}{ Ethnicity } & FRL \\
\hline & & Male & Female & Asian & Black & Hispanic & White & \\
\hline 9th & - & 88 & 68 & 21 & 24 & 27 & 72 & 51 \\
\hline 10th & - & 58 & 66 & 23 & 13 & 20 & 72 & 20 \\
\hline TOTAL & - & 146 & 134 & 44 & 37 & 47 & 144 & 71 \\
\hline
\end{tabular}

\begin{tabular}{|l|c|c|c|c|c|c|c|c|}
\hline DP & ELL & \multicolumn{2}{|c|}{ Gender } & \multicolumn{4}{c|}{ Ethnicity } & FRL \\
\hline & & Male & Female & Asian & Black & Hispanic & White & \\
\hline 11th & - & 56 & 62 & 34 & 10 & 12 & 64 & 30 \\
\hline 12th & - & 59 & 74 & 25 & 11 & 21 & 69 & 30 \\
\hline Certificate & NA & & & & & & & \\
\hline TOTAL & - & 115 & 136 & 59 & 21 & 33 & 133 & 60 \\
\hline
\end{tabular}

Projected Student Participation (2011-2012)

\begin{tabular}{|l|c|c|c|c|c|c|c|c|}
\hline MYP & ELL & \multicolumn{2}{|c|}{ Gender } & \multicolumn{4}{c|}{ Ethnicity } & FRL \\
\hline & & Male & Female & Asian & Black & Hispanic & White & \\
\hline 9th & - & 103 & 56 & 15 & 11 & 20 & 51 & 40 \\
\hline 10th & - & 88 & 68 & 21 & 24 & 27 & 72 & 81 \\
\hline TOTAL & - & 191 & 124 & 36 & 35 & 47 & 123 & 121 \\
\hline
\end{tabular}

\begin{tabular}{|c|c|c|c|c|c|c|c|c|}
\hline \multirow[t]{2}{*}{ DP } & \multirow[t]{2}{*}{ ELL } & \multicolumn{2}{|c|}{ Gender } & \multicolumn{4}{|c|}{ Ethnicity } & \multirow[t]{2}{*}{ FRL } \\
\hline & & Male & Female & Asian & Black & Hispanic & White & \\
\hline 11th & - & 58 & 66 & 23 & 13 & 20 & 72 & 63 \\
\hline 12th & - & 56 & 62 & 34 & 10 & 12 & 64 & 73 \\
\hline Certificate & NA & & & & & & & \\
\hline TOTAL & - & 114 & 128 & 57 & 23 & 32 & 136 & 136 \\
\hline
\end{tabular}

Diploma Activity (2010-2011)

\begin{tabular}{|c|c|c|c|c|c|c|c|c|}
\hline \multirow[t]{2}{*}{ DIPLOMAS } & \multirow[t]{2}{*}{ ELL } & \multicolumn{2}{|c|}{ Gender } & \multicolumn{4}{|c|}{ Ethnicity } & \multirow[t]{2}{*}{ FRL } \\
\hline & & Male & Female & Asian & Black & Hispanic & White & \\
\hline $\begin{array}{l}\text { \# of IB diploma } \\
\text { candidates }\end{array}$ & - & 59 & 74 & 25 & 11 & 21 & 69 & \\
\hline \# of IB diplomas & - & 54 & 66 & 23 & 7 & 18 & 67 & \\
\hline $\begin{array}{l}\text { \# of IB certificate } \\
\text { students }\end{array}$ & - & 5 & 8 & 2 & 4 & 3 & 2 & \\
\hline \# of IB certificates & - & 5 & 8 & 2 & 4 & 3 & 2 & \\
\hline TOTAL & - & 118 & 148 & 50 & 22 & 42 & 138 & \\
\hline
\end{tabular}




\section{School: Forest Hill Community School}

Student Participation (2010-2011)

\begin{tabular}{|c|c|c|c|c|c|c|c|c|}
\hline MYP & ELL & & ider & & & icity & & FRL \\
\hline & & Male & Female & Asian & Black & Hispanic & White & \\
\hline 9th & - & 45 & 43 & 6 & 13 & 45 & 24 & 40 \\
\hline 10th & - & 29 & 30 & 7 & 9 & 31 & 12 & 27 \\
\hline TOTAL & - & 74 & 73 & 13 & 22 & 76 & 36 & 67 \\
\hline
\end{tabular}

\begin{tabular}{|c|c|c|c|c|c|c|c|c|}
\hline \multirow[t]{2}{*}{ DP } & \multirow[t]{2}{*}{ ELL } & \multicolumn{2}{|c|}{ Gender } & \multicolumn{4}{|c|}{ Ethnicity } & \multirow[t]{2}{*}{ FRL } \\
\hline & & Male & Female & Asian & Black & Hispanic & White & \\
\hline 11th & - & 13 & 15 & 4 & 4 & 12 & 8 & 10 \\
\hline 12th & - & 5 & 7 & 2 & 1 & 4 & 5 & 6 \\
\hline Certificate & NA & & & & & & & \\
\hline TOTAL & & 18 & 22 & 6 & 5 & 16 & 13 & 16 \\
\hline
\end{tabular}

Projected Student Participation (2011-2012)

\begin{tabular}{|l|c|c|c|c|c|c|c|c|}
\hline MYP & ELL & \multicolumn{2}{|c|}{ Gender } & \multicolumn{4}{c|}{ Ethnicity } & FRL \\
\hline & & Male & Female & Asian & Black & Hispanic & White & \\
\hline 9th & - & 45 & 52 & 1 & 13 & 48 & 35 & 67 \\
\hline 10th & - & 39 & 33 & 4 & 11 & 39 & 19 & 79 \\
\hline TOTAL & - & 84 & 85 & 5 & 24 & 87 & 54 & 146 \\
\hline
\end{tabular}

\begin{tabular}{|l|c|c|c|c|c|c|c|c|}
\hline DP & ELL & \multicolumn{2}{|c|}{ Gender } & \multicolumn{4}{c|}{ Ethnicity } & FRL \\
\hline & & Male & Female & Asian & Black & Hispanic & White & \\
\hline 11 th & - & 24 & 25 & 7 & 9 & 23 & 10 & 63 \\
\hline 12th & - & 12 & 12 & 4 & 4 & 8 & 8 & 42 \\
\hline Certificate & NA & & & & & & & \\
\hline \hline TOTAL & & 36 & 37 & 11 & 13 & 31 & 18 & 105 \\
\hline
\end{tabular}

Diploma Activity (2010-2011)

\begin{tabular}{|c|c|c|c|c|c|c|c|c|}
\hline DIPLOMAS & ELL & & ider & & & city & & FRL \\
\hline & & Male & Female & Asian & Black & Hispanic & White & \\
\hline $\begin{array}{l}\text { \# of IB diploma } \\
\text { candidates }\end{array}$ & - & 5 & 7 & 2 & 1 & 4 & 5 & - \\
\hline \# of IB diplomas & - & 2 & 1 & & & 1 & 2 & - \\
\hline $\begin{array}{l}\text { \# of IB certificate } \\
\text { students }\end{array}$ & NA & & & & & & & \\
\hline \# of IB certificates & NA & & & & & & & \\
\hline TOTAL & $2-$ & 7 & 8 & 2 & 1 & $\overline{5}$ & 7 & - \\
\hline
\end{tabular}


School: Pahokee Middle-High School

Student Participation (2010-2011)

\begin{tabular}{|c|c|c|c|c|c|c|c|c|}
\hline MYP & ELL & & ider & & & city & & FRL \\
\hline & & Male & Female & Asian & Black & Hispanic & White & \\
\hline 9th & 3 & 68 & 63 & 1 & 63 & 65 & 2 & 110 \\
\hline 10th & 6 & 49 & 82 & 2 & 69 & 57 & 1 & 116 \\
\hline$\overline{\text { TOTAL }}$ & 9 & 117 & 145 & 3 & 132 & 122 & 3 & 226 \\
\hline
\end{tabular}

\begin{tabular}{|c|c|c|c|c|c|c|c|c|}
\hline \multirow[t]{2}{*}{ DP } & \multirow[t]{2}{*}{ ELL } & \multicolumn{2}{|c|}{ Gender } & \multicolumn{4}{|c|}{ Ethnicity } & \multirow[t]{2}{*}{ FRL } \\
\hline & & Male & Female & Asian & Black & Hispanic & White & \\
\hline 11th & - & 11 & 10 & 0 & 4 & 17 & 0 & 20 \\
\hline 12th & - & 13 & 13 & 0 & 4 & 21 & 0 & 23 \\
\hline Certificate & NA & & & & & & 1 & \\
\hline TOTAL & & 24 & 23 & 0 & 8 & 37 & 2 & 43 \\
\hline
\end{tabular}

Projected Student Participation (2011-2012)

\begin{tabular}{|l|c|c|c|c|c|c|c|c|}
\hline MYP & ELL & \multicolumn{2}{|c|}{ Gender } & \multicolumn{4}{c|}{ Ethnicity } & FRL \\
\hline & & Male & Female & Asian & Black & Hispanic & White & \\
\hline 9th & 3 & 70 & 67 & 0 & 75 & 58 & 2 & 121 \\
\hline 10th & 3 & 68 & 63 & 1 & 63 & 65 & 2 & 110 \\
\hline \hline TOTAL & 6 & 138 & 130 & 1 & 138 & 123 & 4 & 211 \\
\hline
\end{tabular}

\begin{tabular}{|c|c|c|c|c|c|c|c|c|}
\hline \multirow[t]{2}{*}{ DP } & \multirow[t]{2}{*}{ ELL } & \multicolumn{2}{|c|}{ Gender } & \multicolumn{4}{|c|}{ Ethnicity } & \multirow[t]{2}{*}{ FRL } \\
\hline & & Male & Female & Asian & Black & Hispanic & White & \\
\hline 11th & - & 18 & 30 & 1 & 17 & 29 & 1 & 43 \\
\hline 12th & - & 11 & 10 & 0 & 4 & 17 & 0 & 20 \\
\hline Certificate & NA & & & & & & & \\
\hline TOTAL & - & 29 & 40 & 1 & 21 & 45 & 1 & 63 \\
\hline
\end{tabular}

Diploma Activity (2010-2011)

\begin{tabular}{|l|c|c|c|c|c|c|c|c|}
\hline DIPLOMAS & ELL & \multicolumn{2}{|c|}{ Gender } & \multicolumn{4}{c|}{ Ethnicity } & FRL \\
\hline & & Male & Female & Asian & Black & Hispanic & White & \\
\hline $\begin{array}{l}\text { \# of IB Diploma } \\
\text { candidates }\end{array}$ & - & 13 & 13 & 0 & 4 & 19 & 3 & 23 \\
\hline \# of IB diplomas & - & 2 & 1 & 0 & 0 & 3 & 0 & 3 \\
\hline $\begin{array}{l}\text { \# of IB certificate } \\
\text { students }\end{array}$ & - & 2 & 0 & 0 & 0 & 1 & 1 & 2 \\
\hline \# of IB certificates & - & 11 & 12 & 0 & 4 & 16 & 3 & 20 \\
\hline \hline TOTAL & - & 13 & 13 & 0 & 4 & 19 & 3 & 23 \\
\hline
\end{tabular}




\section{Appendix B Interview Protocols}

I. Key District Leader

II. District IB Coordinator

III. School Coordinator (MYP/DP)

IV. Teacher

V. Principal

VI. IB Staff/ Resources and Materials Developers

VII. Technical Assistance Provider 


\section{Key District Leader Interview}

Name:

Date:

District:

Explain the purpose of the research, the benefits to the system, and share consent form.

1. Tell me a little bit about your background and preparation. How long have you been the role you're in? What other jobs have you held in the school/ district?

2. How long has there been an IB program in the district? Is it authorized? Where and when? MYP? Where and when? Do you have an overall district strategy?

3. What are the strengths of your IB-MYP program? The challenges?

4. How knowledgeable are you about the access project? Support mechanisms? Summer work? Tools being developed by IB? Describe.

5. Is there a particular strategy to include students of color and/ or students in poverty in the IB program? How well do they do in the program? Are there specific support mechanisms for these students?

6. This grant is about greater access for poor students and students of color. Can you talk about what that means to you? What do you as a school coordinator need to support this work?

7. Ultimately, this grant hopes to improve student performance in the IB program. What do you think it would take to do that? Do you think it is possible to expand access to the program and improve performance?

8. Are you collecting data on IB-MYP students? Describe.

9. In total, you will be participating in this grant for three years. What would be a positive outcome for you and your school, teachers and students? Is there anything in particular you need to support your role as a school coordinator?

10. Anything else I should know about the IB program in your district? 


\section{District Coordinator Interview}

Name:

Date:

District:

Explain the purpose of the research, the benefits to the system, and share consent form.

1. Tell me a little bit about your background and preparation. How long have you been the Coordinator? What other jobs have you held in the school/ district?

2. How long has there been an IB program in the district? Is it authorized? Where and when? MYP? Where and when? Do you have an overall district strategy?

3. What are the strengths of your IB-MYP program? The challenges?

4. What is your role as a district coordinator? How do you spend your time? Has your role changed in the past year?

5. Have you worked with Bill Stroud (or Niki) as part of the MYP access project? If yes, in what ways? What has been useful? What has not been useful? If you could change what they do, how would you change it? How would you rate the overall quality of this work?

6. Did you participate in the summer institute? If yes, what was useful? What was not useful? How would you rate the overall quality of the experience?

7. IB has been developing new tools and supports. I am going to name some of these supports. What do you know about them? Have you used them? Are they useful? What are their strengths? Their weaknesses?

a. Bridge to Success Website

b. Curriculum resource: searchable assessment task bank

c. Curriculum resource: MYP units (unit planner; unit overview; student handouts; summative assessments)

d. Professional development: Online: Curriculum and Assessment Blended Workshops

e. Professional development: Online: Student Support Workshops HAVE YOU HEARD OF THESE OR SIGNED UP FOR THEM? TO BEGIN EARLY 2011

f. Professional development: Assessment Support Centre Mentoring Groups

8. How do students get into the MYP-IB program? What do you believe are the minimum academic prerequisites and personal qualities required for success in the program? Have you seen any inclusion this year of students who would not 
have previously been the program? If so, how do they differ from the typical IB student?

9. Is there a particular strategy to include students of color and/ or students in poverty in the IB program? How well do they do in the program? Are there specific support mechanisms for these students?

10. This grant is about greater access for poor students and students of color. Can you talk about what that means to you? What do you as a school coordinator need to support this work?

11. Ultimately, this grant hopes to improve student performance in the IB program. What do you think it would take to do that? Do you think it is possible to expand access to the program and improve performance?

12. What do you think needs improving in teacher practice and assessment strategies? What do you as a school coordinator need to help you support teacher improvement?

13. In total, you will be participating in this grant for three years. What would be a positive outcome for you and your school, teachers and students? Is there anything in particular you need to support your role as a school coordinator?

14. Anything else I should know about the IB program in your school? 


\section{School Coordinator Interview}

Name:

Date:

School:

Explain the purpose of the research, the benefits to the system, and share consent form.

1. Tell me a little bit about your background and preparation. How long have you been the Coordinator? What other jobs have you held in the school/ district?

2. How long has there been an IB program at this school? Is it authorized? When? MYP? When?

3. What are the strengths of your IB-MYP program? The challenges?

4. What is your role as a school coordinator? How do you spend your time? Has your role changed in the past year?

5. Have you worked with Bill Stroud (or Niki) as part of the MYP access project? If yes, in what ways? What has been useful? What has not been useful? If you could change what they do, how would you change it? How would you rate the overall quality of this work?

6. Did you participate in the summer institute? If yes, what was useful? What was not useful? How would you rate the overall quality of the experience?

7. IB has been developing new tools and supports. I am going to name some of these supports. What do you know about them? Have you used them? Are they useful? What are their strengths? Their weaknesses?

a. Bridge to Success Website

b. Curriculum resource: searchable assessment task bank

c. Curriculum resource: MYP units (unit planner; unit overview; student handouts; summative assessments)

d. Professional development: Online: Curriculum and Assessment Blended Workshops

e. Professional development: Online: Student Support Workshops HAVE YOU HEARD OF THESE OR SIGNED UP FOR THEM? TO BEGIN EARLY 2011

f. Professional development: Assessment Support Centre Mentoring Groups

8. How do students get into the MYP-IB program? What do you believe are the minimum academic prerequisites and personal qualities required for success in the program? Have you seen any inclusion this year of students who would not 
have previously been the program? If so, how do they differ from the typical IB student?

9. Is there a particular strategy to include students of color and/ or students in poverty in the IB program? How well do they do in the program? Are there specific support mechanisms for these students?

10. This grant is about greater access for poor students and students of color. Can you talk about what that means to you? What do you as a school coordinator need to support this work?

11. Ultimately, this grant hopes to improve student performance in the IB program. W

12. 'hat do you think it would take to do that? Do you think it is possible to expand access to the program and improve performance?

13. What do you think needs improving in teacher practice and assessment strategies? What do you as a school coordinator need to help you support teacher improvement?

14. In total, you will be participating in this grant for three years. What would be a positive outcome for you and your school, teachers and students? Is there anything in particular you need to support your role as a school coordinator?

15. Anything else I should know about the IB program in your school? 


\section{Teacher Interview}

Name:

Date:

School:

Explain the purpose of the research, the benefits to the system, and share consent form.

1. Tell me a little bit about your background and preparation. What do you teach? How long have you been a teacher? At this school? Anything else you've taught?

2. What is most satisfying about teaching in the MYP-IB program? What are the challenges?

3. How does the MYP coordinator in your school affect your teaching? What about the IB Coordinator?

4. What kind of MYP-IB professional development have you been involved in? Who delivered it?

5. Have you worked with Bill Stroud (or Niki) as part of the MYP access project? If yes, in what ways? What has been useful? What has not been useful? If you could change what they do, how would you change it? How would you rate the overall quality of this work?

6. Did you participate in the summer institute? If yes, what was useful? What was not useful? How would you rate the overall quality of the experience?

7. IB has been developing new tools and supports. I am going to name some of these supports, and ask you some questions about each one. [What do you know about this resource? Have you used it? Is it useful? Has it affected your teaching? How could it be improved?]

a. Bridge to Success Website:

b. Curriculum resource: searchable assessment task bank No use..

c. Curriculum resource: MYP units (unit planner; unit overview; student handouts; summative assessments)

d. Professional development: Online: Curriculum and Assessment Blended

e. Professional development: Online: Student Support Workshops HAVE YOU HEARD OF THESE OR SIGNED UP FOR THEM? TO BEGIN EARLY 2011:

f. Professional development: Assessment Support Centre Mentoring Groups: 
8. How do students get into the MYP-IB program? What do you believe are the minimum academic prerequisites and personal qualities required for success in the program? Have you seen any inclusion this year of students who would not have previously been in the program? If so, how do they differ from the typical IB student?

9. Is there a particular strategy to include students of color and/ or students in poverty in the MYP-IB program? How well do they do in the program? Are there specific support mechanisms for these students?

10. This grant is about greater access for poor students and students of color. Can you talk about what that means to you?

11. Ultimately, this grant hopes to improve student performance, what do you think it would take to do that? Do you believe it is possible to expand access to the program and also improve performance?

12. Do you feel changes are needed in teacher practice and assessment strategies? What would you like help on in your practice? Assessments?

13. In total, your school will be participating in this grant for three years. What would be a positive outcome for you and your students?

14. Anything else I should know about the IB program in your school? 


\section{School Principal Interview}

Name:

Date:

School

Explain the purpose of the research, the benefits to the system, and share consent form.

1. Tell me a little bit about your background and preparation. How long have you been the Principal? What other jobs have you held in the school/ district?

2. How long has there been an IB program at this school? Is it authorized? When? MYP? When?

3. What are the strengths of your IB-MYP program? The challenges?

4. Have you worked with Bill Stroud (or Niki) as part of the MYP access project? If yes, in what ways? What has been useful? What has not been useful? If you could change what they do, how would you change it? How would you rate the overall quality of this work?

5. Did you participate in the summer institute? If yes, what was useful? What was not useful? How would you rate the overall quality of the experience?

6. IB has been developing new tools and supports. I am going to name some of these supports. What do you know about them? Have you used them? Are they useful? What are their strengths? Their weaknesses?

a. Bridge to Success Website

b. Curriculum resource: searchable assessment task bank

c. Curriculum resource: MYP units (unit planner; unit overview; student handouts; summative assessments)

d. Professional development: Online: Curriculum and Assessment Blended Workshops

e. Professional development: Online: Student Support Workshops HAVE YOU HEARD OF THESE OR SIGNED UP FOR THEM? TO BEGIN EARLY 2011

f. Professional development: Assessment Support Centre Mentoring Groups

7. How do students get into the MYP-IB program? What do you believe are the minimum academic prerequisites and personal qualities required for success in the program? Have you seen any inclusion this year of students who would not have previously been the program? If so, how do they differ from the typical IB student?

8. Is there a particular strategy to include students of color and/ or students in poverty in the IB program? How well do they do in the program? Are there specific support mechanisms for these students? 
9. This grant is about greater access for poor students and students of color. Can you talk about what that means to you? What do you as a school leader need to support this work?

10. Ultimately, this grant hopes to improve student performance in the IB program. What do you think it would take to do that? Do you think it is possible to expand access to the program and improve performance?

11. What do you think needs improving in teacher practice and assessment strategies? What do you as a school leader need to help you support teacher improvement?

12. In total, you will be participating in this grant for three years. What would be a positive outcome for you and your school, teachers and students? Is there anything in particular you need to support your role as a school leader?

13. Anything else I should know about the IB program in your school? 
Interview Protocol

\section{IB Resources and Materials Developers}

April 2011

Name:

Position

In the revised Access Project description it refers to a variety of new tools and resources that are in development. For each of the following please describe:

1. what stage of development you are at

2. the process of development

3. who has been involved and in what capacity

4. what the strategy is for rolling the resource out to schools (who is the target population, and how is it being used or how will it be used)

5. feedback received and modifications, if any, and

6. how these tools will specifically aid the target population in this project or the teachers working with that population

1. MYP Units

2. Assessment Task Bank

3. Blended Professional Development:

Content Specific:

Non-Content Specific:

4. Mentoring Workshops

5. Bridge to Success Website (in general)

6. Anything else?

7.Is there anything in development (new) for Year 3?

8.. From the point of view of the IB organization:

What is the rationale for the design of the new materials?

$>$ What is the theoretical frame for the design of a set of materials that will address the learning needs of a broader range of students?

$>$ How was that determined?

9. What has been the response to resources and tools? 
10. In your opinion, which schools have made the most progress toward meeting the project's goals? Why?

11. In your opinion, which schools have made the least progress toward meeting the project's goals? Why?

12. How are you coordinating your work in tool and resource development with the technical assistance?

13. What are districts and schools saying to you that they need to achieve the access and student achievement goals of this project?

14. What are your plans for Year 3 work? Will you be working any differently with the districts and/ or schools?

15. Will this work sustain beyond the life of the grant? How?

16. Anything I didn't ask you that you think it is important for me to know to better understand the IB resource development process and grant implementation process. 


\section{Technical Assistance Providers}

Interview Protocol

April 2011

1. Describe the work you have been doing, over-all, this year in the schools and districts and how it differs from Year 1's work.

2. What is the balance between work on curriculum content and instructional strategies? How are decisions made about what content to attend to and which strategies to emphasize?

3. Which instructional strategies have been addressed?

4. Describe specific work in each district and each school. How are decisions made about the content of the work?

5. In your opinion, which schools have made the most progress toward reaching the project's goals? Why?

6. In your opinion, which schools have made the least progress? Why?

7. What do you understand to be the Theory of Action in the overall project and how is that guiding decisions about his work?

8. What are the plans for the Summer Institutes and what is the planning process?

9. What are you doing, or planning to do, specifically with district leaders (coordinators) and school leaders (principals, APs, DP and MYP coordinators)?

10. How do you coordinate your work with IB and their tool development process?

11. What are the issues that have emerged from year 2's work? What are your plans for year 3 work?

12. What parts of this work should be sustained beyond the life of the grant? How?

13. Anything I didn't ask you that I should know to understand the technical assistance aspect of this work? 


\section{Appendix C: General Teacher Survey}

June, 2011

Dear Teacher:

This survey of International Baccalaureate (IB) teachers is being conducted by a research team of the Consortium for Policy Research in Education (CPRE) at Teachers College, Columbia University. CPRE was hired in 2009 by International Baccalaureate America to conduct the documentation and evaluation of the three-year Access project funded by the Bill and Melinda Gates Foundation. The documentation and evaluation focuses on providing formative feedback about the implementation of the project, and documenting the impacts of the project on students, teachers, schools and districts. This survey is a source of data for the documentation and evaluation.

Your candid responses on this survey will help us understand more about the implementation of the International Baccalaureate program in your school. Your responses to this survey are completely confidential. Any answer you give will be combined with those of others and reported in aggregate form. No individuals will be identified in any reports produced from these data. Do not put your name on this survey or the attached envelope. The data obtained from this survey will be analyzed by an independent evaluation team not employed by your district. All data from this survey will remain in the sole possession of members of the CPRE research team.

Thank you for your time in completing this survey.

Sincerely,

Thomas B. Corcoran

Director

Consortium for Policy Research in Education

Teachers College, Columbia University 


\section{INSTRUCTIONS}

Please use a pencil or pen (blue or black ink) to complete this survey. When answering a question, please completely fill in the circle ( 1 ) appended to the response you wish to give. If you wish to change your answer, cross out $(\mathbf{X})$ your first answer and fill in the appropriate circle.

Remember there are no right, preferred, or wrong answers to the questions in this survey. In addition to information about the International Baccalaureate program, the survey includes items that ask you to make judgments about the current policies, conditions and practices in your school. We are asking you to be candid in reporting your experiences and perspectives on these issues. All of your responses will be kept confidential. If there is a question you do not wish to answer or one that does not apply to you, you may skip it. We hope you will answer as many questions as possible.

When you have completed the survey, please return it to the MYP Coordinator at your school. It will be returned in a sealed envelope to the independent evaluation team.

\section{TEACHING PRACTICE}

1. How would you describe your current role in your school? (Mark only ONE that best describes your primary position.)

O Humanities (History/Geography) Teacher

O Language A (Language Arts/English) Teacher

O Language B (Foreign Language) Teacher

O Mathematics Teachers

O Science Teacher

O Guidance Counselor

O Arts, Music, or Drama Teacher

O Computer or Technology Teacher

O MYP Coordinator

O DYP Coordinator

O Other (please specify): 
2. Are you a department chairperson?

3. Are you a grade team leader?

4. Are you on the "Core Team?"

5. Are you state certified to teach the subject you selected in question 1?

6.a. Are you IB trained (completed IB teacher training workshop in the subject area selected in question 1)?

b. If yes, what is the highest level you have completed?
Category 1
Category 2
Category 3
O
$\mathrm{O}$
O

7. Please indicate your level of preparation in the primary subject that you teach.

$\begin{array}{ccccc}\text { None } & \text { Some Coursework } & \text { College Minor } & \text { College Major } & \text { Graduate Degree } \\ \mathrm{O} & \mathrm{O} & \mathrm{O} & \mathrm{O} & \mathrm{O}\end{array}$

8. Please mark the grade level(s) you teach this year. (Mark ALL that apply).

9th 10th 11th

12th

$\mathrm{O}$

\section{O}

$\mathrm{O}$

\section{O}

9. Please mark the extent to which you disagree or agree with each of the following statements:

Strongly Somewhat Somewhat Strongly

Disagree Disagree Agree Agree

a. The achievement of my students is primarily due to factors beyond my control.

b. If my students have adequate time, they can master the knowledge and skills expected of them.

c. My students are not ready for problem solving until they have c. acquired the basics.

$\begin{array}{llll}0 & 0 & 0 & 0 \\ 0 & 0 & 0 & 0 \\ 0 & 0 & 0 & 0\end{array}$


9. Please mark the extent to which you disagree or agree with each of the following statements:

Strongly Somewhat Somewhat Strongly

Disagree Disagree Agree Agree

d. Many of the students that I teach are not capable of learning the material I am supposed to teach them.

e. My students assume responsibility for their work.

$\mathrm{O}$

$\mathrm{O}$

O

O

O

f. I use the same criteria for all students to judge the quality of an assignment.

g. My students cannot work in groups without close supervision.

h. My students' success is based more on ability than effort.

O

$\mathrm{O}$

$\mathrm{O}$

$\mathrm{O}$

i. The International Baccalaureate MYP program has the potential to benefit my students.

$\mathrm{O}$

O

$\mathrm{O}$

O

j. What I have learned through International Baccalaureate has

1. improved the quality of my teaching.

O $\quad 0$

O 
10. Please indicate how prepared you feel to do each of the following:

$\begin{array}{ccccc}\text { Not } & \text { Somewhat } & \text { Fairly } & \text { Very } & \text { Not } \\ \text { Adequately } & \text { Prepared } & \text { Well } & \text { Well } & \text { applicable } \\ \text { Prepared } & & \text { Prepared } & \text { Prepared } & \end{array}$

a. Organize a standards-based classroom for the subject(s) I teach.

b. Use rubrics to assess student work.

$\mathrm{O}$

$\mathrm{O}$

$\mathrm{O}$

O

c. Use inquiry-based instruction.

d. Use student work to plan instruction.

$\mathrm{O}$

$\mathrm{O}$

O

O

$\mathrm{O}$

e. Use student data from test results to plan
instruction.

O

$\mathrm{O}$

O

O

f. Use Areas of Interaction with my students.

$\mathrm{O}$

$\mathrm{O}$

O

O

g. Use criterion-related assessments.

\section{$\mathrm{O}$}

O

O

O

h. Use the Learner Profile.

O

O

O

$\mathrm{O}$

i. Use the MYP Unit Planner.

$\mathrm{O}$

$\mathrm{O}$

$\mathrm{O}$

O

j. Include international-mindedness in my teaching.

\section{$\mathrm{O}$}

O

$\mathrm{O}$

$\mathrm{O}$

k. Use of lesson design.

$\mathrm{O}$

O

O

O

1. Use of unit questions to guide student learning.

$\mathrm{O}$

O

0

O

O

m. Use of student-centered discussion.

$\mathrm{O}$

$\mathrm{O}$

O

0

n. Use of student learning teams.

O $\quad 0$

O. Use of formative assessments/ adaptive
instruction.

O

0

0

O

p. Use of tasks requiring high cognitive demand.

O

O

0

O

q. Use of descriptive feedback to students.

O $\quad 0$ 
11. Please indicate the degree to which you use the classroom.
a. Standards-based instruction.
b. Rubrics to assess student work.
$\mathrm{O}$
$\mathrm{O}$
$\mathrm{O}$
$\mathrm{O}$
$\mathrm{O}$
c. Inquiry-based instruction.
O
O
O
O
$\mathrm{O}$
d. Student work to plan instruction.
$\mathrm{O}$
O
O
O
$\mathrm{O}$
e. Student data from test results to plan instruction.
$\mathrm{O}$
$\mathrm{O}$
$\mathrm{O}$
$\mathrm{O}$
$\mathrm{O}$
f. Areas of Interaction.
$\mathrm{O}$
O
$\mathrm{O}$
$\mathrm{O}$
$\mathrm{O}$
g. Criterion-related assessments.
$\mathrm{O}$
O
O
O
$\mathrm{O}$
h. Learner Profile.
$\mathrm{O}$
O
O
$\mathrm{O}$
$\mathrm{O}$
i. MYP Unit Planner.
$\mathrm{O}$
O
O
$\mathrm{O}$
$\mathrm{O}$
j. International-mindedness.
$\mathrm{O}$
$\mathrm{O}$
$\mathrm{O}$
O
$\mathrm{O}$
k. Unit questions to guide student learning.
1. Lesson design.
O
m. Student-centered discussion.
$\mathrm{O}$
O
O
O
$\mathrm{O}$
n. Student learning teams.
$\mathrm{O}$
$\mathrm{O}$
$\mathrm{O}$
$\mathrm{O}$
O
o. Formative assessments/ adaptive instruction.
O
$\mathrm{O}$
O
O
O
p. Tasks requiring high cognitive demand.
O
O
O
O
O
q. Descriptive feedback to students.
$\mathrm{O}$
0
O
$\mathrm{O}$
$\mathrm{O}$ 


\section{THE INTERNATIONAL BACCALAUREATE MIDDLE YEARS PROGRAM (MYP)}

12. Please mark the extent to which you disagree or agree with each of the following statements:
Strongly Somewhat Somewhat Strongly

Disagree Disagree Agree Agree

a. I believe that most of the students in the IB Middle Years Program should move into the IB Diploma Program

b. The IB Middle Years Program is consistent with other instructional initiatives in the school.

c. There is consensus among colleagues in my school that the IB Middle Years Program has improved learning for our students.

d. The IB Middle Years Program has fostered greater collaboration among teachers within my department, grade level and/ or team.

e. I am more enthusiastic about teaching as a result of the IB Middle Years Program.

f. The IB Middle Years Program has contributed to a sense of professional community in my school.

\section{IB MIDDLE YEARS PROGRAM (MYP) PROFESSIONAL DEVELOPMENT}

13. Have you attended any professional development (teacher training) for IB? 
14. Please mark the frequency with which you have done the following:

a. Attended professional development sessions related to IB Middle Years Program led by school staff in the past year.

b. Attended official IB Middle Years Workshops in the past year.

c. Met with other MYP teachers in my school in small study groups.

d. Participated in district-wide MYP professional development.

15. Please mark the usefulness of the following:

a. Participating in professional development sessions related to IB Middle Years Program led by school staff.

b. Participating in official IB MYP professional development workshops.

c. Meeting with other MYP teachers in my school in small study groups.

d. Participating in district-wide MYP professional development.

Never peryear $\begin{array}{ccc}\text { 1-2 times } & \text { Less than } & 1-2 \text { times } \\ \text { month } & \text { per } & \text { Once a } \\ \text { month } & \text { more }\end{array}$

$\mathrm{O}$

$\mathrm{O}$

$\mathrm{O}$

$\mathrm{O}$

$\mathrm{O}$

O

$\mathrm{O}$

$\mathrm{O}$

$\mathrm{O}$

$\mathrm{O}$

$\mathrm{O}$

$\mathrm{O}$

O

O

$\mathrm{O}$

Not Somewhat Very Extremely Not Useful Useful Useful Useful Applicable

$\begin{array}{ccccc}0 & 0 & 0 & 0 & 0 \\ 0 & 0 & 0 & 0 & 0 \\ 0 & 0 & 0 & 0 & 0 \\ 0 & 0 & 0 & 0 & 0\end{array}$




\section{SUPPORT FOR INSTRUCTION}

16. If you need instructional assistance in your classroom, whom do you consult? (Mark all that apply.)
O Principal
O Assistant Principal
O Department Chair
O DP Coordinator
O MYP Coordinator
O Grade Team Leader
O Other teachers in my department
O Other teachers in the school
O Other (please specify): 
17. Please indicate how frequently the following occur:

a. I meet with other teachers in my department or on my team to analyze student work.

b. I meet with other teachers who teach the same students to analyze performance data in relation to standards.

c. I meet with other teachers who teach the same students to discuss the needs of individual students.

d. Faculty in my department share information about effective curricula.

e. I observe other teachers teach a class.

f Other teachers observe my teaching (e.g., planning and coordinating curriculum).

\begin{tabular}{|c|c|c|}
\hline Never & $\begin{array}{c}\text { (e.g., a few } \\
\text { times a } \\
\text { year) }\end{array}$ & $\begin{array}{c}\text { (e.g., once } \\
\text { or twice a } \\
\text { month) }\end{array}$ \\
\hline
\end{tabular}

$\mathrm{O}$

$\mathrm{O}$

$\mathrm{O}$

O

$\mathrm{O}$

$\mathrm{O}$

O

$\mathrm{O}$

$\mathrm{O}$

O

$\mathrm{O}$

$\mathrm{O}$

O

O

O

O

O

O

0 
18. Please indicate whether the following staff provides the specified types of classroom support (Mark all that apply).
Frequently engages me in conversation discuss my about my instruction instruction
Provides Looks at my feedback regarding my instruction students' applicable work
O

O

O

$\mathrm{O}$

$\mathrm{O}$

e. Other teachers on my team

f. Other teachers in my department

g. Other teachers in the "core group"
O

O

O

O

$\mathrm{O}$

O

O
O

O

O

O

$\mathrm{O}$

O

O
O

O

0

O

O

O

O
O

0

0

0

0

0

O
O

O

O

O

O

O

O 


\section{SUPPORT FOR STUDENTS}

19. Please indicate to what extent you agree or disagree with the following statements:

Strongly Somewhat Somewhat Strongly Disagree Disagree Agree Agree

a. We provide adequate support to students in their efforts to be successful in MYP.

b. We actively recruit students of color and poor students into the MYP program.

c. We provide safety nets for students in the MYP program

who may need additional support to be successful in their coursework.

d. We actively engage parents in the support of students in the MYP program.

e. We adequately prepare all students in MYP to continue and be successful in the Diploma Program.

f. We adequately plan as a MYP team to ensure students are engaged in a work load that is manageable.

g. We employ a wide variety of instructional strategies that assist students in being successful.

h. We adequately differentiate instruction in our classes.

i. We use a variety of formative assessments to inform instruction.

j. We give special attention to students of color and poor

j. $\quad$ students to ensure that they continue on and will be successful in the Diploma Program.

k. We routinely review instructional strategies to determine those that are most useful in helping our students learn. 


\section{PROJECT SUPPORT}

20. Please indicate the extent to which you engaged in the following support activities led by project consultants:

a. classroom observations

$\begin{array}{cccc}\text { Never } & \text { Rarely } & \text { Sometimes } & \text { Often } \\ & \text { (e.g., a few } & \text { (e.g., once } & \text { (e.g., once } \\ \text { times a } & \text { or twice a } & \text { or twice a } \\ \text { year) } & \text { month) } & \text { week) }\end{array}$

b.peer coaching

$\mathrm{O}$

$\mathrm{O}$

O

c. unit planning

$\mathrm{O}$

O

O

O

d.developing assessments

O

O

O

O

e. use of areas of interaction

O

O

O

$\mathrm{O}$

f. formulating guiding questions

O

O

O

$\mathrm{O}$

g. working with students in target population

$\mathrm{O}$

O

O

O

h. other

O

0

O

O 
21. Please indicate the usefulness of the following support activities:

$\begin{array}{ccccc}\text { Not } & \text { Somewhat } & \text { Very } & \text { Extremely } & \text { Not } \\ \text { Useful } & \text { Useful } & \text { Useful } & \text { Useful } & \text { Applicable }\end{array}$
a. classroom observations
O
O
O
O
O
b. peer coaching
$\mathrm{O}$
$\mathrm{O}$
O
O
O
c. unit planning
$\mathrm{O}$
O
O
O $\quad 0$
d. developing assessments
0
O
0
O
O
e use of areas of interaction
O
O
O
O
O
f. formulating guiding questions
O
$\mathrm{O}$
0
O
O
g. working with students in target population
$\mathrm{O}$
O
O
O
O
h. other
O
O
O
0
O 
22. Please indicate the degree to which you engaged in the use of the following new tools or resources:

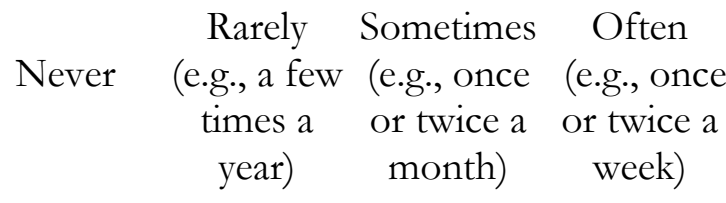
a. Bridge to Success website
$\mathrm{O}$
O
O
$\mathrm{O}$
b. subject-specific blended workshop(s)
$\mathrm{O}$
O
O
$\mathrm{O}$
c. student support on-line workshop(s)
O
O
$\mathrm{O}$
O
d. on-line mentoring
O
O
O
O
e MYP units
O
0
O
O
f. assessment bank
O
0
O
O
g. other
$\mathrm{O}$
O
O
O 
23. Please indicate the usefulness of the following new tools or resources:

$\begin{array}{ccccc}\text { Not } & \text { Somewhat } & \text { Very } & \text { Extremely } & \text { Not } \\ \text { Useful } & \text { Useful } & \text { Useful } & \text { Useful Applicable }\end{array}$
a. Bridge to Success website
$\mathrm{O}$
$\mathrm{O}$
$\mathrm{O}$
$\mathrm{O}$
O
b. subject-specific blended workshop(s)
O
$\mathrm{O}$
O
O
$\mathrm{O}$
c. student support on-line workshop(s)
O
O
O
$\mathrm{O}$
O
d. on-line mentoring
O
$\mathrm{O}$
O
0
O
e. MYP units
O
O
O
O
O
f. assessment bank
O
O
O
0
O
g. other
$\mathrm{O}$
O
O
O
O

\section{CONTEXTUAL INFORMATION}

24. How many years have you taught, including this school year?

25. How many years have you been at this school?

26. What is your average class size?

27. Are you:

Male

Female

$\mathrm{O}$
O 
\#: 1325

28. Do you describe yourself as:

$\begin{array}{ll}\text { O African-American } \\ \text { O } & \text { Asian-American } \\ \text { Hispanic } & \text { Native American } \\ \text { O } & \text { White, Non Hispanic } \\ \text { O } & \text { Multiracial } \\ \text { O } & \text { Other (please specify): }\end{array}$

YOU HAVE COMPLETED THIS SURVEY. THANK YOU VERY MUCH FOR YOUR TIME!

Please return this survey to the MYP Coordinator at your school. It will be returned in a sealed envelope to the independent evaluation team. 